\title{
On the fallacy of using orthogenetic models of rectilinear change in arvicolid teeth for estimating the age of the first human settlements in Western Europe
}

\author{
Paul Palmqvist ${ }^{\mathrm{a} *}$, Mathieu Duval ${ }^{\mathrm{b}, \mathrm{c}}$, Antonio Diéguez ${ }^{\mathrm{d}}$, Sergio Ros-Montoya ${ }^{\mathrm{a}, \mathrm{e}}$ and M $^{\mathrm{a}}$. Patrocinio Espigares ${ }^{\mathrm{a}, \mathrm{e}}$
}

${ }^{a}$ Departmento de Ecología y Geología, Universidad de Málaga, 29071 Málaga, Spain; ${ }^{b}$ Department of Geochronology, Centro Nacional de Investigación sobre la Evolución Humana (CENIEH), Burgos, Spain; ${ }^{c}$ Research School of Earth Sciences, The Australian National

10 University, Canberra, Australia; ${ }^{d}$ Departmento de Filosofía, Universidad de Málaga, 29071 Málaga, Spain; ${ }^{e}$ Museo de Prehistoria y Paleontología, 18858 Orce, Spain

(Received 31 January 2015; accepted 1 March 2015)

Lozano-Fernández et al. (Lozano-Fernández I, Blain HA, López-García JM, Agustí J. 2014. Biochronology of the first hominid remains in Europe using the vole Mimomys savini: Fuente Nueva 3 and Barranco León D, Guadix-Baza Basin, south-eastern Spain. Hist Biol: Int J Paleobiol. doi:10.1080/08912963.2014.920015) recently published age estimates for two Late Villafranchian sites of Orce (Guadix-Baza basin, SE Spain), BL-D and FN-3, which provide some of the earliest evidence of human presence in Western Europe. The estimates were obtained from mean Lm1 values of the water vole Mimomys savini preserved in the sites and a couple of rectilinear equations derived in the Atapuerca TD section for site age on tooth length. However, this chronometric tool has problems that discourage its use in biostratigraphy, including: (1) the assumption of an orthogenetic trend of Lm1 increase during the evolution of the M. savini/Arvicola lineage; (2) the use of a chronology for the TD section not supported by original ESR data; (3) the discrepancies between the mean Lm1 values published for the TD levels $\lrcorner$ and (4) the chronological ranges predicted when the standard deviations are used, which are exceedingly large as to be of value for biostratigraphic purposes. As a result, the pseudo numerical ages estimated for the Orce sites only add noise to the timing of the first human dispersal in Europe, which is based on a combination of results from well-established techniques such as palaeomagnetism, biostratigraphy and ESR.

Keywords: numerical dating; biostratigraphy; Mimomys savini; Early Pleistocene; orthogenesis; hasty generalisation

\section{Introduction}

Up to the mid-1990s, most archaeologists and palaeoanthropologists believed that there was no significant habitation in Europe before Middle Pleistocene times (Carbonell and Rodríguez 1994; Roebroeks and van Kolfschoten 1994; Dennell and Roebroeks 1996), thus favouring a 'short chronology' for the earliest permanent human settlements (i.e., $\sim 600-500 \mathrm{ka}$, as evidenced in the Middle Pleistocene sites of Boxgrove and Mauer; Roberts et al. 1994; Wagner et al. 2010). However, this chronology was shortly overturned by the discovery of Early Pleistocene human remains, lithic grtefacts and cut marks on large mammal bones in a number of sites from Spain, including Barranco León (BL-D) and Fuente Nueva-3 (FN-3) in Orce, dated to $\sim 1.4-1.2 \mathrm{Ma}$ (Martínez-Navarro et al. 1997; Oms et al. 2000; Palmqvist et al. 2005; Duval et al. 2012; Espigares et al. 2013; Toro et al. 2013); Sima del Elefante (TE9c) and Gran Dolina (TD-6) in the Atapuerca karstic complex, dated to $\sim 1.2$ and $\sim 0.8 \mathrm{Ma}$, respectively (Carbonell et al. 1999, 2008; Bermúdez de Castro et al. 1997, 2010; Falguères et al. 1999; Berger et al. 2008; Arnold et al. Forthcoming 2015); and, more recently, Vallparadís Estació in the VallèsPenedès basin, dated to $\sim 0.9-0.8 \mathrm{Ma}$ (Martínez et al. 2010, 2013, 2014; Duval et al. 2011, Forthcoming 2015;
García et al. 2013a, 2013b; for controversy on the evidence of human presence at this site, see MadurellMalapeira et al. 2012), and Barranc de la Boella in a terrace system of the lower Francolí River basin, dated to 0.96-0.78 Ma (Vallverdú et al. 2014). In addition, the finding of abundant human remains and Oldowan tools at Dmanisi, a Georgian site located at the gates of Europe and dated to $\sim 1.8 \mathrm{Ma}$, pointed to a chronology slightly younger than the Olduvai subchron for the first dispersal of the genus Homo out of Africa (Gabunia and Vekua 1995; Gabunia et al. 2000, 2002; de Lumley et al. 2002; Vekua et al. 2002; Lordkipanidze et al. 2005, 2007, 2013).

These findings have led to intense debate on a number of issues related to the first human arrival in Europe, including: (1) the chronology of the dispersal event; (2) the anatomical affinities, taxonomic status, populational variability and techno-cultural developments of the dispersing population; (3) the possible dispersal routes $\lambda$ and (4) the ecological context and climatic conditions in which this event took place (e.g., Martínez-Navarro and Palmqvist 1995; Arribas and Palmqvist 1999; Carbonell et al. 1999, 2010; Bar-Yosef and Belfer-Cohen 2001; Dennell, 2003; Antón and Swisher 2004; MartínezNavarro 2004, 2010; Dennell and Roebroeks 2005; Nikitas and Nikita 2005; Palmqvist et al. 2005, 2007; 
Turner and O'Regan 2007; Agustí et al. 2010; Moncel 2010; Agustí and Lordkipanidze 2011; Jiménez-Arenas et al. 2011a, 2011b; Moyano et al. 2011, 2013; Bermúdez de Castro and Martinón-Torres 2013; Muttoni et al. 2013; García et al. 2014; Vallverdú et al. 2014). For this reason, any new chronology proposed for these localities must be analysed with caution, especially in the case of BL-D, FN-3 and TE9c, the sites that document the earliest evidence of human occupation in Western Europe below the Jaramillo subchron (Carbonell et al. 2008; Bermúdez de Castro et al. 2010; Duval et al. 2012; Espigares et al. 2013; Toro et al. 2013).

The sites of BL-D and FN-3 (Orce, Guadix-Baza basin) preserve the earliest evidence of human presence during the Early Pleistocene (Calabrian), including the finding of a human deciduous, lower first molar tooth (BL02-J54-100) at BL-D (Toro et al. 2013), huge lithic assemblages at both sites (Palmqvist et al., 2005; Moyano et al. 2011) and abundant evidence of anthropic activities on large mammal bones (Espigares et al. 2013). The chronology of BL-D, estimated as close to $1.4 \mathrm{Ma}$, indicates that by the moment BL02-J54-100 is the oldest fossil hominin of Western Europe. The two lithic assemblages show strong similarities and can be ascribed to the Oldowan tradition (i.e., 135 Mode 1 technological system). They are mainly composed of small, non-modified flakes and cores. Large limestone manuports are also present, especially in the case of FN-3. In addition, taphonomic analysis of modified bones (Espigares 2010) has evidenced the prevalence of curved fractures with oblique angles and smooth edges (Villa and Mahieu 1991), which indicates a pattern of fresh bone breakage. Surface damage caused during breakage of bones (e.g., percussion notches, impact flakes and negative flake scars) has been also identified, which allows interpreting hammer stone breakage as the origin of fractures. Cutmarks are not abundant and appear mainly on the long bones of large-sized animals, with a predominance of incisions on the shaft, although sawing marks and scraping marks are also documented. The morphology, location and distribution of these marks relate them with different phases of carcasses processing (dismembering, defleshing, evisceration and periosteum removal; Espigares 2010; Espigares et al. 2013; Toro et al. 2013).

In a paper recently published in Historical Biology, Lozano-Fernández, Blain, et al. (2014) studied the first lower molar teeth of the water vole Mimomys savini (Rodentia, Mammalia) preserved at BL-D and FN-3, in an attempt to estimate the chronology of these Late Villafranchian sites. Specifically, their main goal was

to test the chronologies of FN-3 and BL-D (in particular, BL-D, as the numerical chronology published for this site displays a very high error range) and the chronological relationship between these two sites and TE9c at Sima del Elefante, using the evolution of the vole $M$. savini for this
For doing so, (1) they estimated the mean lengths of the lower first molars (Lm1) of the adult specimens of $M$. savini recovered from FN-3 (3.23 $\pm 0.11 \mathrm{~mm} ; N=42)$ and BL-D (3.28 $\pm 0.09 \mathrm{~mm} ; N=34)$; and (2) used a couple of linear regression equations for site age on mean Lm1 values that were derived previously by LozanoFernández, Cuenca-Bescós, et al. (2013) for levels TD4 to TD6-1 of the Atapuerca Gran Dolina site (TD section), whose ages are comprised, according to their interpretation, between 1.01 and $0.8 \mathrm{Ma}$. Depending on the equation used, the numerical ages extrapolated for the Orce sites using this procedure were the following: $1.13 \pm 0.12 \mathrm{Ma}$ (Equation (1)) and $1.26 \pm 0.13 \mathrm{Ma}$ (Equation (2)) for BL-D, and $1.09 \pm 0.12 \mathrm{Ma}$ (Equation (1)) and $1.20 \pm 0.12 \mathrm{Ma}$ (Equation (2)) for FN-3, respectively (Lozano-Fernández, Blain, et al. 2014: Table 1).

According to Lozano-Fernández, Blain, et al. (2014), the new ages reported are overall consistent with the chronologies usually accepted for these sites, which in their opinion provides evidence of the reliability of their 'chronometric' approach. However, in the case of BL-D these ages are younger than the one currently considered for this site $(\sim 1.4 \mathrm{Ma})$, which is derived from a combination of biostratigraphy, magnetostratigraphy and optical dating techniques (Martínez-Navarro et al. 1997; Oms et al. 2000; Arribas and Palmqvist 2002; Palmqvist et al. 2005; Agustí et al. 2010; Martínez-Navarro 2010; Toro et al. 2013). In fact, the ages reported by LozanoFernández, Blain, et al. (2014) for this site are similar to the chronology of level TE9c from Atapuerca Sima del Elefante $(1.22 \pm 0.16 \mathrm{Ma})$, which is based on cosmogenic nuclides (Carbonell et al. 2008). However, it is worth noting that the electron spin resonance (ESR) dating method applied to optically bleached quartz grains and fossil teeth provided numerical ages of $1.43 \pm 0.38 \mathrm{Ma}$ for BL-D (Toro et al. 2013) and $1.19 \pm 0.21 \mathrm{Ma}$ for FN-3 (Duval et al. 2012), respectively. Taking into consideration their error ranges, these age estimates overlap to a greater or lesser extent with the ones reported by LozanoFernández, Blain, et al. (2014), specially in the case of those provided by Equation (2), and also overlap with the age currently accepted for level TE9c, $1.22 \pm 0.16 \mathrm{Ma}$ (Carbonell et al. 2008). For this reason, LozanoFernández, Blain, et al. (2014) concluded 'If we consider the error range obtained in different datations from these three sites, we can conclude that these sites correspond to a similar chronological range from 1.1 to $1.4 \mathrm{Ma}$.'

However, biostratigraphic evidence indicates that the Orce sites are older than TE9c. Specifically, the microfaunal assemblages of $\mathrm{FN}-3$ and $\mathrm{BL}$ are both characterized by the association of $M$. savini with Allophaiomys aff. lavocati (Agustí et al. Forthcoming 2015). According to Toro et al. (2013), there is a continued trend in arvicolids to increasing tooth size and hypsodonty 
through the Pleistocene. Given that the molar teeth of A. lavocati preserved at BL-D are smaller and more archaic (i.e., less hypsodont) than those of TE9c, this suggests that BL-D is older. However, it should be noted that the rationale behind these arguments is similar to the one used in the orthogenetic approach that we criticise here (i.e., the assumption of orthogenetic change and absence of regional effects, see later). In addition, the absence of suid remains at BL-D and FN-3 is a biostratigraphic marker that argues also for an older chronology for these localities in comparison with TE9c. The reason is that pigs are apparently absent from Europe in the chronological range comprised between 1.8 and 1.2 Ma, as evidenced in the huge fossil assemblages of Dmanisi (Georgia), Pirro Nord (Italy), Apollonia-1 (Greece), Sainzelles (France) and Orce (Venta Micena, Barranco León and Fuente Nueva-3), which preserve the best European record of Early Pleistocene large mammals. In contrast, suid remains are abundantly preserved in all

240 European sites situated before the post Tasso Faunal Unit, which marks the base of the Late Villafranchian at $\sim 1.8 \mathrm{Ma}$ (Rook and Martínez-Navarro 2010). These localities include Fonelas P-1 in the Guadix-Baza basin, dated to $2.0 \mathrm{Ma}$, in which suid remains were ascribed to Potamochoerus magnus (Arribas et al. 2009), and many others with the presence of Sus strozzii. After their disappearance in Europe at the end of the Olduvai subchron, suids arrived again in Europe at $\sim 1.2 \mathrm{Ma}$, as documented in TE9c (Carbonell et al. 2008), Untermassfeld, Germany (1.1-1.0 Ma; Gúerin and Faure 1997), Vallparadís EVT12 ( 1.0 Ma; Madurell-Malapeira et al., 2010) and Le Vallonnet, France (with an age close to the Jaramillo subchron; Moullé et al. 2006), while in the Guadix-Baza basin they have been reported at several

255 Middle Pleistocene localities such as Cúllar de Baza or La Solana del Zamborino (Martín-Penela 1988; Alberdi et al., 2001; Jiménez-Arenas et al. 2011b). For this reason, the absence of suids from BL-D and FN-3 may tentatively be interpreted as suggesting for both sites a biochronological age older than $\sim 1.2 \mathrm{Ma}$.

In any case, the overall apparent agreement of the results of Lozano-Fernández, Blain, et al. (2014) with the existing chronostratigraphical framework of the Orce sites cannot hide the fallacy of using a rectilinear approach, which has been already criticised on both conceptual and methodological grounds (e.g., Martin 2014; Palmqvist et al. 2014). Consequently, a further scrutiny of the inconsistencies and potential pitfalls associated to this 'biochronological tool' is warranted before accepting without reservation the ages obtained with it for the Orce sites.

The main issues in the paper of Lozano-Fernández, Cuenca-Bescós, et al. (2013) criticised by Martin (2014) and Palmqvist et al. (2014) were the following: (1) the logic behind their chronometric tool represented a 'fallacy of hasty generalization', because the rectilinear equations obtained in the study of a local stratigraphic section (Atapuerca Gran Dolina, levels TD4 to TD6-1) were assumed to be generalisable to other stratigraphic sequences (e.g., BL-D and FN-3 of Guadix-Baza basin in the study of Lozano-Fernández, Blain, et al. 2014); (2) these equations were based on tooth measurements from a limited set of samples (six for Equation (1) and five for Equation (2) of Lozano-Fernández, Blain, et al. 2014), which had a high level of age uncertainty, covered a short chronological range $(\sim 0.2 \mathrm{Ma})$ and included small numbers of specimens in three cases $(9 \leq N \leq 12$ for layers TD4, TD6-1 and TD6-2); (3) this 'vole clock' approach assumed a monotonic (i.e., constant rate) increase in tooth size during the evolution of the $M$. savini lineage, which implied an orthogenetic, rectilinear pattern of change; (4) the samples analysed showed small, statistically non-significant differences between their mean Lm1 values; (5) as a result, the changes in Lm1 mean values through the Atapuerca TD section were better described by a random walk, or even by a series of independent events, than by a genuine evolutionary tendency that followed a linear-straight trend $d_{\Lambda}$ and (6) the application of this methodology to other localities older than the Atapuerca TD levels (e.g., the Orce sites) implies that the ages estimated for them are extrapolated instead of interpolated, which increases the risk of statistical uncertainty for the results obtained. In what follows, we focus on the first fourth points.

\section{If this is Belgium, it must be Tuesday}

According to Lozano-Fernández, Blain, et al. (2014, p. 1), the Early/Middle Pleistocene arvicoline M. savini shows a tendency that 'involves a reduction in the percentage of the adult population with an enamel islet and Mimomys ridge, and an increase in the size of its first lower molar (m1).' More specifically, they stated 'this increase was defined by Lozano-Fernández, Cuenca-Bescós, et al. (2013) and Maul et al. (2014) as a linear tendency, thus establishing the size of the M. savini $\mathrm{m} 1$ as a biochronological tool.' LozanoFernández, Blain, et al. (2014) justify the use of their approach for the Orce sites as follows:

This extrapolation has been possible because an almost constant trend towards increasing size (i.e., increasing $\mathrm{m} 1$ length) in the evolution of the water rat lineage (M. savini/ Arvicola) has been observed (Maul et al. 2014). This trend is a consequence of their semiaquatic way of life, because an increase in size enables the water rats to maintain in a more efficient way their body temperature. (Maul et al. 2014)

Therefore, the main assumption of the 'chronometric tool' of Lozano-Fernández, Blain, et al. (2014) is that an almost constant trend towards increasing tooth size took place in the evolution of the water vole lineage. This was clearly expressed in their previous paper: 
If a relationship can be established between the size of individuals and their chronology, and the trend that governs a species' increase in size can be determined, then the chronologies of different sites can be estimated based on the size of the individuals of that species recovered at those particular sites. (Lozano-Fernández, Cuenca-Bescós, et al. 2013, p. 96)

Such logic (the 'vole clock' approach according to Martin 2014) is similar to the one used in geochronological methods based on natural radioactive decay, a stochastic process at the atomic level in that the probability that a given nucleus of an unstable isotope will decay is constant over time (Masini et al. 1999a, 1999b). For this reason, the use of this argument in biostratigraphy reminds Tuesday, this must be Belgium', directed in 1969 by Mel Stuart: if the 'biochronological method' of LozanoFernández, Cuenca-Bescós, et al. (2013), Lozano-Fernández, Blain, et al. (2014) and Lozano-Fernández, BañulsCardona, et al. (2014) proved valid, it would imply that the length of the first lower molar tooth of $M$. savini increased in a way as regular and predictable as the one of those old packaged sightseeing tours designed for time-sensitive travellers, where the nonplussed tourists were expected to rush from one country to another in a short time interval (and eventually became confused about the country in which they were). For a discussion on the weakness and inconsistency of the use of this reasoning in biochronology, see Braga and Rivas (1986).

In fact, the rectilinear equations used by LozanoFernández, Cuenca-Bescós, et al. (2013), Lozano-Fernández, Blain, et al. (2014) and Lozano-Fernández, BañulsCardona, et al. (2014) for deriving chronological estimates assume that each mean Lml value of $\mathrm{M}$. savini would correspond to a single numerical age in outh-western Europe during the late Early Pleistocene (i.e., the 'if this is Belgium, it must be Tuesday' argument). According to Palmqvist et al. (2014), such reasoning represents a case of 'fallacy of hasty generalization' (see Walton 1999), as it

370 implies that: (1) each of the samples of $M$. savini taken consecutively through the Atapuerca TD section has a single mean tooth length and a given age; (2) any sample whose mean Lm1 value is identical to one of the TD samples should have the age of the latterand (3) if a sample of $M$. savini has a different mean tooth length, its age could be interpolated (or extrapolated) using the function that relates tooth size and sample age in the Atapuerca TD sequence. The falsity of this reasoning (i.e., that two samples with identical tooth size values could not have different ages) is clear, because although a couple of samples from the Atapuerca TD sequence show the same mean Lm1 values, TD4 $(3.43 \pm 0.14 \mathrm{~mm})$ and TD6-3 $(3.43 \pm 0.17 \mathrm{~mm})$, their ages are 1.01 and $0.86 \mathrm{Ma}$, respectively (Lozano-Fernández, Cuenca-Bescós, et al. storyline of the film of Mel Stuart (or the logic of the biochronological method of Lozano-Fernández, CuencaBescós, et al. (2013), Lozano-Fernández, Blain, et al. (2014) and Lozano-Fernández, Bañuls-Cardona, et al. (2014) it should be noted that any travel may be affected by delays and the tourists might not have arrived to Belgium on Tuesday, as programmed (in our case, the age of the samples used for deriving the equations of site age on tooth size can be incorrect, as noted by Palmqvist et al. 2014 and discussed in $\triangle$ more detail later).

In addition, when Lozano-Fernández, Blain, et al. (2014) extrapolate the results obtained for the Atapuerca TD section (Northern Spain) to the Guadix-Baza basin (Southern Spain), they implicitly assume that regional effects (e.g., climatic and environmental factors) should not have any significant influence on the metric parameters of M. savini in the Spanish record (i.e., according to their approach, the evolution of mean Lm1 values would only be driven by chronological factors). Such an assumption must be considered with caution, as biogeographic provincialism is known to be a major source of uncertainty for chronological inferences, even within a limited area such as the Iberian Peninsula (e.g., see Gómez Cano et al. 2011). In fact, the small mammal record from the GuadixBaza basin is sharacterised by a significant Mediterranean influence, which results in a high number of endemic or local species (Agustí et al. Forthcoming 2015). This faunal provincialism further limits the possibilities of performing larger scale correlations.

Furthermore, the 'vole-clock' approach of LozanoFernández, Cuenca-Bescós, et al. (2013) and LozanoFernández, Blain, et al. (2014) is not new. In fact, there are a number of precedents of biostratigraphic analyses aimed to estimating site age using rectilinear trends for size and shape in 'evolutionary series' of fossils, including arvicoline rodents and mammoths (Maul et al. 1998a, 1998b, 2014; Masini et al. 1999a, 1999b; Vangengeim and Pevzner 2000; Pevzner and Vangengeim 2001; Paupe et al. 2010; Martínez et al. 2014). For example, Maul et al. (1998a, 1998b) studied a huge number of fossil populations from several arvicolid lineages, including water voles, which covered a time span of $\sim 1.8 \mathrm{Ma}$. They measured several metric variables and dental indexes that estimate adaptive features of the first lower molar tooth linked to dietary $\mathfrak{S}$ pecialisation and chewing efficiency. Then, they adjusted the data series using linear, logarithmic and polynomial approaches, and also an equation of exponential decay (Masini et al. 1999a, 1999b). The patterns of change detected included periods of directional evolution punctuated by fluctuations in the rate of change, which alternated with periods of stasis and random variation. For this reason, although it is true that there is a genuine long-term trend to increasing tooth size in arvicolids, as proposed by Lozano-Fernández, CuencaBescós, et al. (2013) and Lozano-Fernández, Blain, et al. 
(2014), and that this trend can provide the first hints for the biostratigraphic position of the samples studied (Maul et al. 2014), the marked fluctuations in the rate of evolutionary change and the abundant reversions observed suggest that this trend can be useful as a biochronological indicator only in a very general sense (Palmqvist et al. 2014).

Figure 1 shows the relationship in the $M$. saviniArvicola lineage between mean Lm1 values ( $X$-axis) and site age ( $Y$-axis) for a high number of fossil and modern European localities $(N=130)$ that cover a time span of $\sim 1.8 \mathrm{Ma}$ (data from Maul et al. 2014: Appendix A). This graph shows that, overall, there is a genuine, continentalscale 'gradualistic' trend to increasing tooth size through time in the water vole lineage, as affirmed by LozanoFernández, Cuenca-Bescós, et al. (2013) and LozanoFernández, Blain, et al. (2014). In addition, the rectilinear equation fitted by ordinary least squares (OLS) regression to these data (Figure 1) is not based exclusively on a single, local stratigraphic section, as in the case of the equations of Lozano-Fernández, Cuenca-Bescós, et al. (2013) and Lozano-Fernández, Blain, et al. (2014), which would ensure generalisability for the age predictions obtained with it. However, Figure 1 also shows a high scatter of points around the regression line, which is reflected in the wide $95 \%$ confidence interval (CI) for the age predictions obtained with this Equation $( \pm 444 \mathrm{ka})$. This scatter indicates, on the one hand, the existence of a large amount of regional variation and minor reversals superimposed on the trend (e.g., Lm1 varies between 3.59 and $4.35 \mathrm{~mm}$ among modern European populations of Arvicola). On the other, it probably results in part also from age uncertainties in the independent dating of the localities sampled, as most of them have not been dated with numerical methods.

Age (ka)

Figure 1. Mean values of lower first molar length (Lm1, in $\mathrm{mm}$ ) and mean age estimates (in ka) for a number of Pleistocene localities of Europe $(N=130)$ with record of the $M$. savini/Arvicola lineage. The rectilinear equation (solid line) was derived using the OLS regression method. Dashed lines represent the 95\% CIs above and below the regression line. Data for BL-D and FN-3 are from Lozano-Fernández, Blain, et al. (2014: Table 1). Data for Atapuerca TD levels are from Lozano-Fernández,Cuenca-Bescós, et al. (2013: Table 1). Data for Atapuerca TE9-13 are from Cuenca-Bescós et al. (2010: Table 3). Data for other localities are from Maul et al. (2014: 
In fact, the ages assumed for most European localities are based on biochronological evidence, in some cases combined with magnetostratigraphy, which is an additional limiting factor for the reliability of such a large-scale correlation.

If the equation of Figure 1 for site age on tooth size is applied to the mean Lm1 values of the $M$. savini teeth from BL-D and FN-3 (3.23 and $3.28 \mathrm{~mm}$, respectively; data from Lozano-Fernández, Blain, et al. 2014: Table 1), the mean chronologies calculated for these sites are 0.808 and $0.760 \mathrm{Ma}$, respectively. Both estimates are clearly younger than the ages currently accepted for these sites $(\sim 1.4$ and $\sim 1.2 \mathrm{Ma}$, respectively) and also than those obtained by Lozano-Fernández, Blain, et al. (2014) using the rectilinear equations for site age on tooth size derived from samples TD4 to TD6-1, as noted before. In addition, the 95\% CI's of the estimates for BL-D and FN-3 are 1.252-0.364 Ma and 1.204-0.316 Ma, respectively. Obviously, such wide age ranges seriously limit the interest of this approach for biostratigraphic dating purposes.

In the case of Atapuerca TE9c, the arvicolid teeth from this site have been ascribed to a new species of water vole, Arvicola jacobaeus, in spite of the fact that M. savini is recorded in a number of Spanish sites with chronologies that are older (e.g., BL-D and FN-3) and younger (e.g., Atapuerca TD levels) than TE9c, respectively. According to Cuenca-Bescós et al. (2010, p. 567-568), the molar teeth of A. jacobaeus are 'related to Mimomys and to Arvicola in terms of size, morphology and enamel differentiation'. For this reason, and given that Figure 1 shows a gradualistic trend in Lm1 values through the evolution of the whole $M$. savini-Arvicola lineage, we have applied the rectilinear equation for site age on tooth size to the mean Lm1 value of A. jacobaeus from levels TE9-TE13 of Atapuerca Sima del Elefante $(3.48 \mathrm{~mm}$; data from Cuenca-Bescós et al. 2010: Table 3). This provides an age estimate of only $0.567 \mathrm{Ma}$, which is clearly younger than the chronology currently accepted for the site $(\sim 1.2 \mathrm{Ma})$ and is also in clear disagreement with the magnetostratigraphic data available, which unequivocally indicate a Matuyama age for this locality (Carbonell et al. 2008). In addition, the 95\% CI for the age estimate (1.010-0.123 Ma) calculated using the standard deviation of $\mathrm{Lm} 1$ values in this locality ( $\sigma= \pm 0.21 \mathrm{~mm}$; Cuenca-Bescós et al. 2010: Table 3 ) is again very wide.

The huge discrepancies between the age estimates calculated for BL-D, FN-3 and TE9c with the equation of Figure 1 and those derived by Lozano-Fernández, Blain, et al. (2014), Duval et al. (2012), Toro et al. (2013) and Carbonell et al. (2008) for these sites can be explained by the fact that the Spanish localities from Guadix-Baza and Atapuerca tend to scatter close to the upper limit of the 95\% CI around the regression line for the M. savini-
European sites with similar mean Lm1 values; see Figure 1). As explained in the next section, this situation probably results in part from a problematic chronological interpretation of the existing data-set. In any case, the $Y$ intercept of the equation depicted in Figure 1 $(3919.102 \pm 209.977)$ is lower than the one of the equation derived from the five TD samples analysed by Lozano-Fernández, Cuenca-Bescós, et al. (2013), which is depicted in Figure 3 (4991.608 \pm 187.698). Such difference is statistically significant according to a Student $t$-test ( $t=3.817, p=0.0038$, two-tailed) and reflects that, for a given chronology, the tooth specimens collected in samples from the Iberian Peninsula tend to be larger on average than those from other localities placed at higher latitudes. This is probably related to differences in resource quality and availability between Southern and Central Europe (Palmqvist et al. 2014).

Figure 2 shows the variations during the evolution of the $M$. savini-Arvicola lineage in the values of the 'enamel band differentiation index’ (SDQ; Heinrich 1978). This morphometric index, which is estimated as the ratio between the widths of the posterior and anterior enamel walls measured at the salient angles of the tooth (see details in Maul et al. 2014), has been used as a biostratigraphic marker for the Mimomys-Arvicola transition in the Middle Pleistocene (e.g., Von Koenigswald and Van Kolfschoten 1996). The graph shows a general trend through time to lower mean SDQ values in the water vole lineage. However, although the trend is statistically significant, there is again a high scatter of points around the OLS regression line, which results from the combined effects of regional variation, fluctuations in the rate of change and uncertainties in the chronology of the localities sampled. As a result, the $95 \%$ CI for the mean ages derived from this rectilinear Equation $( \pm 429 \mathrm{ka})$ is very high. The age estimates (mean and range) obtained using the mean SDQ values of BL-D and FN-3 (153.4\%, average for both sites; Lozano-Fernández, Agustí, et al. 2013: Table 2) and TE9-TE13 (132\%; Cuenca-Bescós et al. 2010: Table 3) are 0.792 Ma (range: 1.221$0.363 \mathrm{Ma}$ ) and $0.546 \mathrm{Ma}$ (range: $0.975-0.117 \mathrm{Ma}$ ), respectively. Once more, these chronologies are considerably younger than the pre-Jaramillo ages currently accepted for the sites and their CI's are exceedingly large as to be of value for biostratigraphic purposes. In addition, Figure 2 shows the absence of a trend for SDQ values in the Atapuerca TD samples, which probably explains why Lozano-Fernández, Cuenca-Bescós, et al. (2013) and Lozano-Fernández, Blain, et al. (2014) did not use this index in their 'biochronological tool'.

A similar attempt to measure an orthogenetic series running in a straight line was the study by Vangengeim and Pevzner (2000) of the evolution of mammoth molars in the Archidiskodon-Mammuthus phyletic lineage (see also Pevzner and Vangengeim 2001). In this study, 
Mean values of the enamel band differentiation index (SDQ, in \%) and mean age estimates (in ka) for a number of Pleistocene localities of Europe $(N=143)$ with record of the M. savini/Arvicola lineage. The rectilinear equation (solid line) shows a trend towards lower values of SDQ in arvicolids with continuously growing molars (Maul et al. 2014) and was derived using the OLS regression method. Dashed lines represent the $95 \%$ CIs above and below the regression line. Data for BL-D, FN-3 and Atapuerca TD levels are from Lozano-Fernández, Agustí, et al. (2013). Data for Atapuerca TE9-13 are from Cuenca-Bescós et al. (2010: Table 3). Data for other localities are from Maul et al. (2014: Appendix A).

lamellar frequency (LF, the number of enamel plates in a 10-cm length of crown; Maglio 1973) was measured in the third upper molars recovered from nine Pleistocene localities of Europe. Three of these localities, Liventsovka (2.4 Ma), Sinyaya Balka (0.95 Ma) and Předmosti (26.5 $\mathrm{ka}$ ), were employed for fitting the following area cotangent curve, which was in turn used to derive 'biometric dates' for the other six sites:

$$
\begin{aligned}
T= & 1.62\left[\left(0.141 e^{0.623 M}+1\right) /\left(0.141 e^{0.623 M}-1\right)\right] \\
& -1.6427 \mathrm{Ma},
\end{aligned}
$$

where $T$ is age site (in Ma) and $M$ is mean $\mathrm{LF}$ value.

In spite of the absence of an in-depth evaluation of the error in age determination, which should include all sources of uncertainty involved (as in any numerical dating approach), the age estimates derived by Vangengeim and Pevzner (2000) from their equation apparently agreed well with the chronologies reported for most localities. The exceptions were Mosbach, Ilford and Balderton, whose 'biometric dates' $(300,82$ and $32 \mathrm{ka}$, respectively) were inconsistent with the ages currently accepted for these sites $(600-500, \sim 200$ and $\sim 160 \mathrm{ka}$, respectively; Lister and Sher 2001: Appendix). However, according to Vangengeim and Pevzner (2000), the estimate for Balderton agreed with a new ${ }^{14} \mathrm{C}$ date for a bone sample from this locality $(29.6 \pm 0.6 \mathrm{ka})$.

In the case of FN-3, the application of this equation to the single third upper molar of Mammuthus meridionalis unearthed $[\mathrm{LF}=5.87$; value estimated using data on 
mesiodistal $\mathrm{M}^{3}$ length $(255.4 \mathrm{~mm})$ and total number of plates (15) from Ros-Montoya 2010] provides a 'biometric age' of only $0.635 \mathrm{Ma}$. This Middle Pleistocene chronology, which would correspond in Europe to the species thontherib, is clearly younger than the one accepted for the site, based on ESR ( $\sim 1.2 \mathrm{Ma}$; Duval et al. 2012), and also contradicts the magnetostratigraphic evidence available, which unequivocally indicates a Matuyama age (Martínez-Navarro et al. 1997; Oms et al. 2000; Espigares et al. 2013). In the case of the nearby site of Barranco del Paso (BP), a quarry stratigraphically located $\sim 8 \mathrm{~m}$ below FN-3 with a chronology estimated in $\sim 1.3 \mathrm{Ma}$ based on magnetostratigraphy (Scott et al. 2007), the mean LF value of the specimens (4.8, average for two $\mathrm{M}^{3}$ teeth; $L=180$ and $195 \mathrm{~mm}$, respectively, a total of nine plates in both cases; Ros-Montoya 2010) provides a 'biometric age' of $1.772 \mathrm{Ma}$, which is also in disagreement with the existing chronological estimate of the site.

However, it is worth noting that lamellar frequency is affected by the degree of tooth wear, as the LF values of strongly worn teeth are considerably lower than those of slightly worn specimens. For this reason, Vangengeim and Pevzner $(2000,77)$ recommended that 'in determining tooth ages by the biometric method, when data on degree of tooth wear are unavailable, the dates obtained should be considered as the maximum possible, i.e., not older than the estimated value.' Differences in tooth wearing can be discarded for explaining the discrepancies between the 'biometric ages' and the chronologies currently accepted for FN-3 and BP. In the case of FN-3, the single $\mathrm{M}^{3}$ tooth unearthed from this locality is heavily worn in its mesial part, which indicates an age at death for this individual of $\sim 35$ years (Ros-Montoya 2010). This suggests that if this tooth were unworn (and preserved more enamel plates), the 'biometric age' would have been even younger (i.e., the discrepancy with the actual age of the site would increase). In the case of the two $\mathrm{M}^{3}$ teeth from $\mathrm{BP}$, they were still erupting and probably belonged to an individual of 22-24 years of age at death (Ros-Montoya 2010), which allows to discard an age overestimation resulting from tooth wearing.

It could be also argued that these 'biometric ages' are based on mean LF values calculated from very few individuals (only one in the case of FN-3) and that lamellar

815 frequency is a highly variable trait in elephant populations (Vangengeim and Pevzner 2000). For this reason, we used the area cotangent curve for estimating the 'biometric age' of a larger sample of $\mathrm{M}^{3}$ teeth $(N=16)$ from the Valdarno collections housed in the Museum of Natural History of Florence, Italy. The 'biometric age' obtained from the mean LF value (4.5; Ros-Montoya unpub. data) is $1.03 \mathrm{Ma}$, an estimate that is again younger than the ages currently accepted for these specimens $(2.6-1.8 \mathrm{Ma})$. This confirms that the orthoevolutionary approach of Vangengeim and Pevzner (2000) has no interest in biostratigraphy.
In any case, the rectilinear trend of LF in mammoth molars used by Vangengeim and Pevzner (2000) for deriving the 'biometric dates' of European localities seems to be, at first sight, overall in agreement with the study of Lister and Sher (2001) of 14 sites whose age spans from 2.6 Ma to $15 \mathrm{ka}$, which also showed a largely directional trend for this dental trait (Lister and Sher 2001: Figure 2). However, although LF is critical to elephant dental shearing function (and thus has adaptive value), its significance can be misleading, because it relies on its relationship to changes in both plate number and molar length: if an increase in lamellar frequency is achieved through a decrease in molar length rather than through an increase in plate number, the shearing ability of the tooth will remain unchanged (Maglio 1973). For this reason, the apparently gradualistic, unidirectional trend in LF values reported by Vangengeim and Pevzner (2000) is somewhat equivocal, because mammoth tooth length varied through the Pleistocene. In fact, the trait that has functional significance by itself is the raw number of plates in the complete upper third molars, which does not show a rectilinear trend; instead, plate number increased in several significant steps spread across the interval 2.6$0.15 \mathrm{Ma}$, alternating periods of change and stasis (Lister and Sher 2001: Figure 3A).

The examples discussed above show the lack of success in the attempts to develop biochronological tools based on 'evolutionary series' of fossils for numerical dating of Pleistocene localities. In spite of this, the chronometric temptation seems to be very strong in the biostratigraphy of Quaternary mammals (Palmqvist et al. 2014). A good example is the study of Paupe et al. (2010), who recently wrote:

The degree of anatomical evolution of the Romain-laRoche mammoth population, which is near the most ancient $M$. primigenius, allows us to date the site of the uppermost part of the biozone MNQ 24 (end of the marine isotopic stage [MIS] 6) corresponding about to the end of the penultimate glaciation, or less probably of the very early beginning of MNQ 25 zone (last interglacial, MIS 5 e). (Paupe et al. 2010, p. 130)

It is probably difficult to conceive a biochronological reasoning that more closely approaches the argument 'if this is Belgium, it must be Tuesday'.

\section{Problems in the chronological interpretation of layers TD4 to TD6}

Lozano-Fernández, Cuenca-Bescós, et al. (2013: Table 1) used a chronology for the Atapuerca TD section that shows a nearly perfect and continuous age succession (i.e., 1.01, $0.99,0.96,0.86,0.83_{\curlywedge}$ and $0.80 \mathrm{Ma}$ for levels TD4, TD5b, TD5a, TD6-3, TD6-2 jand TD6-1, respectively). According to the caption of Table 1 in Lozano-Fernández, CuencaBescós, et al. (2013), these ages corresponded to 'the mean 
Figure 3. Rectilinear equation (solid line) derived using the OLS regression method for site age (in ka) on mean Lm1 values (in mm) of the $M$. savini specimens sampled from Atapuerca TD levels ( $N=5$; data from Lozano-Fernández,Cuenca-Bescós, et al. 2013: Table 1). Dashed lines represent the 95\% CIs (CI) above and below the regression line. This figure shows also the chronologies estimated with the equation for the mean Lm1 values of BL-D, FN-3 (data are from Lozano-Fernández, Blain, et al. 2014: Table 1) and TE9-13 (data are from Cuenca-Bescós et al. 2010: Table 3), the 95\% CI's for these estimates and the age estimates obtained for the means plus/minus one and two standard deviations $(\sigma)$, which would encompass $68 \%$ and $95 \%$ of the population parameter, respectively.

between the upper and lower ages of each level given by Falguères et al. (1999) and Moreno-García (2011).' In addition, they assumed a mean age error of $\pm 110 \mathrm{ka}$ for each TD level studied, again supposedly based on an average of the age errors reported by Falguères et al. (1999) and Moreno-García (2011). Given such chronological interpretation, the numerical dates of the Atapuerca TD sequence are perfectly ordered, suggesting also a rather constant deposition time of $\sim 30 \mathrm{ka}$ for each sublevel of TD6 and TD5. However, this seems to be an artificial construction, which is not supported by original data from Falguères et al. (1999) and Moreno-García (2011). In fact, a careful look at these papers shows a quite different pattern. Three teeth from the Aurora stratum
(TD6-2) were dated by the combined U-series/ESR method, providing ages of $676 \pm 101,762 \pm 114$ and $770 \pm 116 \mathrm{ka}$, respectively. This resulted in a weighted mean age of $730 \pm 63$ ka for TD6-2 (Falguères et al. 1999), which contrasts with the age considered by LozanoFernández, Cuenca-Bescós, et al. (2013) for this sublevel, $830 \pm 110 \mathrm{ka}$. The age of Falguères et al. (1999) was recently corrected by Duval et al. (2012) to $766 \pm 80 \mathrm{ka}$, based on the age underestimation observed in one tooth sample. In addition, preliminary ESR age estimates from Moreno-García (2011), based on optically bleached quartz grains, are somewhat more scattered than those provided by Lozano-Fernández, Cuenca-Bescós, et al. (2013). Specifically, according to the data provided by Moreno- 
García (2011), weighted mean ages of $0.57 \pm 0.07 \mathrm{Ma}$ $(N=5), \quad 1.02 \pm 0.14 \mathrm{Ma} \quad(N=2), \quad 0.65 \pm 0.08 \mathrm{Ma}$ $(N=3), \quad 0.78 \pm 0.09 \mathrm{Ma}(N=3)$ and $0.77 \pm 0.32 \mathrm{Ma}$ $(N=1)$ were obtained for TD3-4, TD5 (note that no mention is made to TD5a and TD5b sublevels in MorenoGarcía 2011), TD6-3, TD6-2_ and TD6-1, respectively. Although definitive ESR ages should be anyway provided and discussed in a forthcoming paper by Moreno-García, it is nevertheless difficult to conceive how Lozano-

1000 Fernández, Cuenca-Bescós, et al. (2013) came to their chronological interpretation of the lower levels of the Atapuerca TD sequence. In addition, no sedimentological evidence supports a continuous and constant sedimentation rate for the sedimentary infilling of the Gran Dolina cave (Campaña et al. 2014), as suggested by the age estimates of Lozano-Fernández, Cuenca-Bescós, et al. (2013).

Obviously, these approaches have a direct and major impact on the reliability of the 'chronometric tool' of

1010 Lozano-Fernández, Cuenca-Bescós, et al. (2013): given their doubtful chronological interpretation, which results in a rather monotonic increase in the age of each successive TD level, they affirmed

there is no constant acceleration or deceleration in this increase, which rules out exponential and logarithmic models as possible approaches to the evolutionary trend of this trait. That leaves the linear trend model (linear regression) as the best fit for approximating the reality of the situation.

1020 Actually, given the data discussed above, the 'reality of the situation' seems to be an artefact resulting from a biased chronological interpretation, which is so far not supported by the available chronological estimates of Falguères et al. (1999) and Moreno-García (2011).

Martínez et al. (2014) and Lozano-Fernández, BañulsCardona, et al. (2014) used a similar approach for estimating the chronologies of Vallparadís EVT7 and Barranc de la Boella, respectively (it is worth noting, however, that a revised ESR date of $0.858 \pm 0.087 \mathrm{Ma}$ for layer EVT7 has been available recently; Duval et al. 2015). According to Martínez et al. (2014), the mean Lm1 value of the M. savini specimens from EVT7 is close to the means of TD5a and TD5b. In their opinion - and using again the 'if this is Belgium, it must be Tuesday' argument

1035 - this indicates a chronology of 0.98-0.95 Ma for EVT7, based on the data provided by Cuenca-Bescós et al. (2011) and references therein. Such precision for a one million years time range $(30 \mathrm{ka}, \sim 3 \%)$ is significantly higher than the one usually provided by any standard method of numerical dating (e.g., ESR, OSL and TCN; $1 \sigma$ error $>10 \%$ ), which raises additional doubts on the reliability of this biochronological inference. In addition, the paper of Cuenca-Bescós et al. (2011) was not intended to provide a chronology for the lower levels of the
Atapuerca TD section. Instead, they studied the variations in diversity of the faunal succession from the Gran Dolina record and tentatively correlated each level to a MIS. For this reason, the extrapolation by Martínez et al. (2014) of these results to derive such a precise chronology for the TD5 sublevels, without considering any of the potential uncertainties that are commonly associated to these correlations, is extremely hazardous.

The study of Lozano-Fernández, Bañuls-Cardona, et al. (2014) on Barranc de la Boella is another ${ }_{\Lambda}$ case of oversimplified and biased chronological interpretation of an existing data-set. This paper represents also an abuse of the fallacy of hasty generalisation in biochronology, as the authors wrote

The mean size of $M$. savini from level 2 of Barranc de la Boella corresponds to a population between the top of TD4 of Gran Dolina and Fuente Nueva 3 and Barranco León D in Orce (in accordance with Lozano-Fernández, CuencaBescós, et al. 2013). As the evolution of M. savini involves an increase in size (Viriot et al. 1990; Chaline et al. 1999; , Lozano-Fernández, Agustí, et al. 2013; LozanoFernández, Cuenca-Bescós, et al. 2013), size values suggest an age for level 2 of between 1.19 and $1 \mathrm{Ma}$ (Fuente Nueva 3 corresponds to $1.19 \mathrm{Ma}$ according to Duval et al. 2012, 2012; the top of TD4 corresponds to $1 \mathrm{Ma}$ according to Moreno 2011; Moreno et al. 2012).

(Lozano-Fernández, Bañuls-Cardona, et al. 2014, p. 727)

In fact, if the rectilinear equation of Figure 3 is used for the mean Lm1 value of Barranc de la Boella $(3.32 \pm 0.102 \mathrm{~mm})$, an age estimate of $1.147 \mathrm{Ma}$ is obtained, although it is worth noting that this mean value is based on only a couple of teeth (Lozano-Fernández, Bañuls-Cardona, et al. 2014: Table S2).

\section{Problems of sample size and population variability}

The first rectilinear equation used by Lozano-Fernández, Blain, et al. (2014) for estimating the chronology of BL-D and FN-3 provided age estimates that were slightly younger than those currently accepted for these sites. This equation was derived from mean estimates of site age and Lm1 values for six levels (TD4, TD5b, TD5a, TD6-3, TD6- $2_{\lambda}$ and TD6-1) of Atapuerca Gran Dolina (LozanoFernández, Cuenca-Bescós, et al. 2013: Table 1, Figure 3A). Of these levels, TD6-3 departed from the 'evolutionary trend' described by the others, as it showed a lower mean Lm1 value than expected. This reversal of the direction of change indicates that although a directional trend to increasing tooth size does exist in the $M$. savini lineage, this is so only in terms of average net change and does not represent a genuine case of monotonic, rectilinear change towards larger teeth. In fact, this trend is better described by a random walk (Palmqvist et al. 2014). In addition, it is worth noting that among the three sublevels of TD-6, TD6-3 is the only one that provided a 
statistically reliable mean Lm1 value, as it was based on a high number of teeth $(N=101)$. In contrast, the other two sublevels of TD-6 were represented by low numbers of specimens $(N=9$ for TD6-2 and $N=10$ for TD6-1; 1105 Lozano-Fernández, Cuenca-Bescós, et al. 2013: Table 1). Consequently, to exclude sublevel TD6-3 from the adjustment of the regression equation can hardly be justified from a statistical point of view.

The second equation used by Lozano-Fernández, Blain, et al. (2014), in which level TD6-3 was omitted from the analysis, provided age estimates that were in better agreement with those previously published for the Orce sites, especially in the case of FN-3. However, this equation is incorrect, as noted by Palmqvist et al. (2014).

1115 Figure 3 reproduces the correct equation for these data, derived with statistical package SPSS (Norusis 2011). Its application to the mean Lm1 values of the Early Pleistocene sites results in the following predictions of mean age and their corresponding $95 \%$ CIs, based on the

1120 standard errors of the $Y$-intercept and the slope: $1251 \pm 57.8 \mathrm{ka}$ for BL-D, $1194 \pm 50.8 \mathrm{ka}$ for FN-3 and $962 \pm 31.5 \mathrm{ka}$ for TE9-TE13, respectively. Given that the Lm1 means of BL-D and FN-3 are outside the range of Lm1 values from TD4 to TD6-1, their ages are extrapolated and, as a result, their 95\% CI's are greater than the one for TE9-TE13. The chronologies obtained with the corrected equation are also younger than the ages currently accepted for BL-D ( 1.4 Ma) and, especially, for TE9c $(\sim 1.2 \mathrm{Ma})$, although in the case of BL-D the CI's of the ESR age and the 'biometric estimate' overlap.

However, the usual procedure in geochronology is to use the mean of the parameter (mean Lm1 value in the case of Lozano-Fernández, Blain, et al. 2014) plus/minor one or two standard deviations $(\sigma)$, which would encompass the distribution of the population parameter $68 \%$ and $95 \%$ of the time, respectively. Figure 3 shows also these chronological intervals, which are very wide. Specifically, the age ranges predicted by the equation of Figure 3 for the mean Lm1 $\pm 2 \sigma$ values of the populations of $M$. savini/A.

1140 jacobaeus from the three sites are: 1506-997 ka for BL-D, 1402-985 ka for FN-3, and 1448-476 ka for TE9-TE13, respectively. Such chronological ranges result in a considerable age uncertainty for BL-D and FN-3 $(\sim 500 \mathrm{ka}$ in both cases) and especially for TE9-TE13 (nearly one million years).

In addition, the mean Lm1 values of levels TD4 to TD61 used by Lozano-Fernández, Cuenca-Bescós, et al. (2013) for deriving their rectilinear Equations (as well as the numbers of specimens on which they are based) differ from other datasets. For example, in the case of TD4, the level for which the discrepancies between datasets are greater, the mean $\mathrm{Lm} 1 \pm \sigma$ values published are: $3.43 \pm 0.14 \mathrm{~mm}$ ( $N=12$, Lozano-Fernández, Cuenca-Bescós, et al. 2013), $3.38 \pm 0.14 \mathrm{~mm} \quad(N=5, \quad$ Martínez et al. 2014), $11553.34 \pm 0.14 \mathrm{~mm}(N=12$, Lozano-Fernández 2014) and
$3.34 \mathrm{~mm}$ ( $\sigma$ not available; $N=10$, Lozano-Fernández, Agustí, et al. 2013; Lozano-Fernández, Bañuls-Cardona, et al. 2014). In which concerns the Orce sites, the values used by Lozano-Fernández, Blain, et al. (2014) for BL-D and FN-3 are $3.23 \pm 0.11 \mathrm{~mm} \quad(N=34)$ and $3.28 \pm 0.09 \mathrm{~mm}(N=42)$, respectively. In contrast, Martínez et al. (2014) reported estimates for BL-D and FN-3 of $3.25 \pm 0.12 \mathrm{~mm}(N=53)$ and $3.28 \pm 0.10 \mathrm{~mm}(N=45)$, respectively. Finally, Lozano-Fernández, Agustí, et al. (2013) and Lozano-Fernández, Bañuls-Cardona, et al. (2014) provided a mean $\mathrm{Lm} 1$ value for both sites of $3.23 \mathrm{~mm} \quad(N=132)$, which differs from the pooled averages obtained using the estimates of Lozano-Fernández, Blain, et al. (2014) and Martínez et al. (2014) for each of these sites, $3.26 \mathrm{~mm}$ in both cases $(N=76$ and 98 , respectively). A similar situation applies to Vallparadís, because the Lm1 estimates provided by Martínez et al. (2014) and Lozano-Fernández (2014) are also slightly different, $\quad 3.48 \pm 0.152 \mathrm{~mm} \quad(N=23) \quad$ and $3.47 \pm 0.150 \mathrm{~mm}(N=22)$, respectively.

Given such discrepancies among the data-sets available, the rectilinear equations derived for TD4 to TD6-1 from each data-set would be different (and also the chronologies predicted by these equations) if different Lm1 means are used for BL-D and FN-3. Obviously, this casts additional doubts on the reliability of the age estimates obtained with the 'chronometric tool' of Lozano-Fernández, Cuenca-Bescós, et al. (2013) and Lozano-Fernández, Blain, et al. 2014).

Finally, the low number of samples used to derive the rectilinear equations is an additional limiting factor: depending on whether six or five sub-layers of the Atapuerca TD section are considered for the least-squares adjustment of the regression equation, the chronologies derived for FN-3 and BL-D may increase by $10-11 \%$ (Lozano-Fernández, Blain, et al. 2014). Such a high variation shows that the final age estimates considered for these sites will be strongly influenced by the number of samples used as data input in the regression equation.

\section{Orthogenesis rides again? The fallacy of rectilinear evolution}

Orthogenesis (or 'programme-evolution'; Lang 1923) was a term coined in 1893 by Wilhelm Haacke - who was inspired in the ideas of Carl von Nägeli - and popularized by Theodor Eimer - who was originally a Lamarckian to designate the process of evolution by 'definitely directed variation' (Eimer 1898). Literally, the concept of orthogenesis meant evolution in a straight line, held to a regular and predetermined course by forces internal to the organism (e.g., from a mystical 'inner perfecting principle' to a general trend in development due to the constitutional restrictions of the 'germinal materials'; Guyer 1922; Metcalf 1928). This would result in non-random variation 
and, eventually, the appearance and fixation of nonadaptive or useless traits that could lead species to their degeneration and even extinction.

The main evidence for orthogenesis came from the palaeontological literature of the late-nineteenth and earlytwentieth centuries, which was full of examples of 'unidirectional evolutionary series' that resemble the one assumed by Lozano-Fernández, Cuenca-Bescós, et al. (2013) and Lozano-Fernández, Blain, et al. (2014) for

1220 increasing Lm1 values in M. savini. According to Mayr (1976, p. 46): 'At a time when Lamarckian ideas were still prevailing, such series were interpreted as a proof of an intrinsic tendency towards perfection. Now we question not only this interpretation, but even the fact of undeviating, straight-line evolution.'

Orthogenesis assumed that variation was limited and not randomly oriented with respect to the direction of evolutionary change within a population, as stated by the Darwinian paradigm. Instead, the advocates of orthogen-

1230 esis believed that variation was always oriented in the same sense, a view that implied an internalist view of evolution in which the 'guiding force' for changing in a unilinear fashion came from within the animal and not from any external teleological cause. Therefore, natural selection was powerless or insignificant for orthogeneticists, who considered that 'Darwin's utilitarianism' (Bowler 1992) was a mistake and that the species had an inherent tendency to evolve relentlessly and steadily in the same direction over indefinitely prolonged periods of time, 1240 regardless of influences directly involved in the interaction between organisms and environment (e.g., Marsh 1874; Cope 1885, 1896). As a result, the species would be carried automatically along a definite trajectory in the direction marked out by internal factors controlling variation.

1245 Morphological trends arising from developmental constraints could, then, overcome the action of natural selection (Bowler 1979, 1989; Devillers and Chaline 1989; Lister et al. 2005; Levit and Olsson 2006; Ullet 2013). For this reason, Simpson (1944) proposed the use of a more descriptive term for orthogenesis, 'rectilinear evolution', which uncoupled the description of the evolutionary pattern from the causes that determined it. In contrast to orthogenesis, orthoselection was defined as environmental selection continuing to operate in a given direction for a long time, which would promote the progress and continuance of a trend, thus simulating an adaptive orthogenesis (Gould 2002, p. 352). Both conceptions, orthogenesis and orthoselection, agree with the assumptions of the biochronological model used by LozanoFernández, Blain, et al. (2014) for dating BL-D and FN-3, as explicitly acknowledged previously by LozanoFernández, Cuenca-Bescós, et al. (2013, p. 96).

Orthogenesis-based change assumed that: (1) morphological traits changed gradually, which in an extreme view et al. 2013; Lozano-Fernández, Blain, et al. 2014) would imply that evolutionary change took place at uniform, constant rate (i.e., 'phylogenetic inertia' and rectilinear change of Simpson 1944; see also Blomberg and Garland 2002); and (2) once a lineage took an evolutionary path, the direction of anagenetic change remained the same, even if it eventually resulted in non-adaptive morphological change and extinction. An illustrative example of this misconception was the classical interpretation of Megaloceros giganteus. This giant deer, with a height at shoulder of $1.8 \mathrm{~m}$ and an antler span of up to $3.5 \mathrm{~m}$, was envisioned as the final product of a long evolutionary series of ever enlarging antlers, a trend outside the control of natural selection that ultimately led to the extinction of this bizarre lineage. Among the peregrine explanations for how the immense antlers contributed to the extinction of Megaloceros, Hart (1830) proposed that the deer died of apoplexy when the copious blood supply that nourished the velvets of their antlers rushed in upon the brain after the velvets were shed. In contrast, Johnston (1903) considered as possible causes for extinction miring in ponds, tangling in trees and $\mathrm{S}_{\mathrm{R}}$ terilisation. However, Simpson (1953) offered a more realistic explanation for the hypertely of antlers in Megaloceros, based on the notion of allometry or relative growth (Huxley 1932): given that the antlers of modern cervids show positive allometry on body size, which results from a trend in the static allometry of smaller deer (Huxley 1931), the enormous antlers of $M$. giganteus would have been the inevitable consequence of positive selection for body size increase and sexual selection in the lineage. This allometric relationship explains the possible negative effects of the disproportionate increase in antler size of M. giganteus as a sort of 'pleiotropic disadaptation', because such effects would be counterbalanced by the advantageous increase in body size (Simpson 1953; Gould 1974; Lister 1994). Other classical examples of orthogenesis and evolution directed towards doom (Gould 1977; Schopf 1977) include the tendencies ever to secrete more calcium carbonate for protection in hippurite shells and cribimorph bryozoans, or to suffocation by overcoiling in Jurassic Gryphaea, trends which 'having once started continue inevitably to the point where their exaggeration puts the organism so much out of harmony with its environment as to cause its extinction' (Lang 1923, p. 11).

Strictly mechanistic versions of orthogenetic-like explanations not based on vitalistic forces have been also proposed based on the idea of constraints to evolutionary change: "if an organism is so constructed that there are narrow limits to the ways in which it could change without losing viability, then evolutionary change would in practice only be possible in those permitted directions' (Kemp 1999, p. 222). These views were further elaborated during the mid-twentieth century under the concept of typostrophism by German palaeontologist Otto 
H. Schindewolf, an advocate of discontinuous or transilient evolution, who claimed that there is a limited number of stable morphologies that can be constructed. As a result, evolutionary change would consist of 1325 spontaneous jumps, or saltations from one such stable morphology to another; intermediate states could not exist because they would be unstable states, which is why they are absent from the fossil record (Kemp 1999, p. 31). Schindewolf's 'typostrophic' theory envisioned the 1330 evolution of lineages as a three-stage 'life cycle' dictated by factors internal to the organisms, including: (1) the nearly synchronous origin through large transformational steps (i.e., without transitional forms) of the main body architectures found within the lineage (typogenesis); (2) their progressive elaboration, diversification and differentiation (typostasis); and (3) the decline, degeneration and loosening of the morphological constraints embodied in the type (typolysis), including $\Omega^{\text {verspecialisation and }}$ gigantism (Schindewolf 1945, 1950; DiMichele 1995).

1340 According to Schindewolf, the origin of species or any higher taxonomic category was due to single mutations whose phenotypic effects depended on the time in ontogeny at which the mutation acted. If late in ontogeny, the effects would be slight and a new species would arise; if early, the effects would be greater (macromutation) and a new class or phylum would appear: as an example of extreme saltationism, Schindewolf (1936) speculated that the first bird may have hatched from a reptile's egg.

Orthoselection (as first named by Plate 1903) was an alternative process that could also lead to a pattern of rectilinear evolution. Unlike orthogenesis, orthoselection could fit theoretically within the Darwinian paradigm, as it was not envisioned as a product of internal forces limiting or guiding variation. Orthoselection entailed that either of

1355 the two following conditions was met: (1) the action of a widespread and uniform environmental selective pressure held constant in both direction and rate of change over a long period of time; or, alternatively and (2) the existence of a constraint that would ganalise genetic variation in a linear direction of adaptive change (Gould 2002). Neither of both alternatives was demonstrated in the study of Lozano-Fernández, Blain, et al. (2014) and there is no reason to suppose that they constitute plausible explanatory options.

The ideas of orthogenesis and orthoselection represented a popular and extreme view of phyletic gradualism guided by an innate trend or by directional selection sustained through time, respectively. However, in spite of occasional resurgences in the literature, orthogenesis was definitely refuted by the times of the New Synthesis and orthoselection was considered as evidentially non-conclusive, if not a purely fictional construction based on a misinterpretation of the evidence available for large-scale adaptive trends (Simpson 1944,
1998; Gould 2002). As a result, orthogenesis and orthoselection are now only historical curiosities (Bowler 1992; Ulett 2014). In spite of this, the rectilinear model of directional evolution developed by Lozano-Fernández, Cuenca-Bescós, et al. (2013) and Lozano-Fernández, Blain, et al. (2014) matches the expectations of both conceptions, as noted before, because it assumes that phyletic evolution to continued tooth size increase took place in the Mimomys lineage at constant, monotonic rate. However, it is worth noting that although the fossil record shows that gradual evolution does exist, it never follows a strictly rectilinear path, because its direction and rate of change vary constantly as a result of variations in the selective regime caused by fluctuations in climate and environment (e.g., Milankovitch cycles during the Quaternary), variations in resource quality and availability, dispersal and isolation of populations that may result in bottlenecks and speciation events (e.g., the Iberian lynx), etc. As a result, evolutionary trends consist of episodes of directional change at varying evolutionary rates that alternate with intervals of morphological stasis, and even with reversals of the direction of change (Simpson 1944; Mayr 1976), as exemplified by European mammoths (Lister 1992, 2013; Lister and Sher, 2001; Lister et al., 2005; Ros-Montoya et al., 2012) and water voles (Devillers and Chaline 1993; Lister 2013; Maul et al. 2014; Palmqvist et al. 2014). This is also the case of the trend to increasing mean Lm1 values in the populations of M. savini from levels TD4 to TD6-1 of Gran Dolina, which shows a reversal in TD6-3 (Lozano-Fernández, CuencaBescós, et al. 2013: Figure 1), the only sub-layer of TD-6 that shows enough specimens for providing statistically reliable estimates of mean Lm1 values. For this reason, any attempt to develop a biochronological method for numerical dating based on the assumption of rectilinear, monotonic change in an 'evolutionary series' of fossils (e.g., Vangengeim and Pevzner 2000 for mammoths; Lozano-Fernández, Cuenca-Bescós, et al. 2013 for water voles) is doomed to failure. In the case of LozanoFernández, Cuenca-Bescós, et al. (2013) and LozanoFernández, Blain, et al. (2014), their apparent rectilinear trend for M. savini is also very likely biased by their chronological interpretation of layers TD4 to TD6, as discussed before.

\section{On progress and directionality in evolution}

According to Gould (1977), palaeontological debate has been dominated by three essential questions on the history of life on Earth. These questions, which formulation preceded evolutionary thought and found no resolution within the Darwinian paradigm, still impregnate major contemporary issues in modern palaeobiology. The first is if the history of life has definite directions (e.g., to increasing complexity and/or diversity); the second relates 
to the motor of organic change (e.g., internal to the organisms or external resulting from environmental fluctuations); and the third raises the tempo of organic change (e.g., gradual jos. punctuated). These questions arise, to a greater or lesser extent, in the approach of Lozano-Fernández, Cuenca-Bescós, et al. (2013) and Lozano-Fernández, Blain, et al. (2014), which assumes phyletic size gradualism in a directional, unilinear fashion and - although not explicitly acknowledged - apparently not subject to environmental control during the evolution of the M. savini lineage (i.e., orthogenesis).

During pre-evolutionist times, catastrophists were, for the most part, progressionists who envisioned each new episode of life as a distinct improvement leading inexorably towards the modern creation. In contrast, Lyell had a vision linked to the Newtonian timelessness of endlessly revolving planets, in which the species came and went but the world was ever the same (Gould 1977). The evolutionary context was impregnated during the late-

1450 nineteenth century by the 'directionalist' yersus 'steadystatist' debate, with vitalists and finalists speaking of inevitable direction in evolutionary change (e.g., orthogenesis) and most strict Darwinians maintaining that evolution only involves adaptation to changing local environments, which fluctuate stochastically and show no directional trend through time (Gould 1977). Given that natural selection, the basic Darwinian mechanism, offered no rationale for the appearance of 'progress' in the history of life, most orthogeneticists viewed evolutionary change as a gradual, straight-line process that was upwardly directed and guided internally without any influence of the environment. As a result, time and morphology maintained a one-to-one association in a simple concomitant relationship in the most classic conceptions of evolution-

1465 ary palaeontology (Montagu 1955): the longer the time elapsed, the more advanced the morphological development. This is precisely the main assumption of the 'biometric tools' developed by Vangengeim and Pevzner (2000) and Lozano-Fernández, Cuenca-Bescós, et al. (2013) and Lozano-Fernández, Blain, et al. (2014), who interpreted the increase in lamellar frequency of mammoths and the increase in tooth length of arvicolids in terms of increasing chewing efficiency.

One of the most notable examples of progressive 1475 evolution of complex from simpler forms was the classic reconstruction of the horse family from the Eocene to the present. The branching tree of equids, which shows multiple speciation events (MacFadden 1994), was envisioned as a straight-line trend to increasing body size and tooth crown height, and to decreasing the number of side toes, in a travel that began 'some sixty million years ago with Eohippus and emerged into the present firmly seated on the back of modern Equus' (Montagu, 1955, p. 14). As a result of this oversimplification, the family Equidae has been frequently cited in the literature on evolution, as well as depicted in museum diagrams, as a prime example of Cope's law (i.e., the gradual trend toward body size increase over time), in spite of a number of parsimony analyses made for resolving the phylogenetic interrelationships of North American fossil horses and elucidating their patterns of body-size evolution, which have shown no evidence of such trend (MacFadden 1994; Gould and MacFadden 2004). This was clearly pointed up by Mayr (1976, p. 42): ᄉ

The study of those few evolutionary lines, for instance the horses, for which enough fossil material is available to permit detailed analysis shows that evolution is only rarely smoothly rectilinear. Progress, instead, is by trial and error. One organ may run far ahead, the others lag behind; periods of stagnation may alternate with periods of explosive advance. There is a continued trend toward improved adaptation to the shifting environment, but to call this purposive only clouds the issue.

Apart from orthogenesis, a number deterministic 'evolutionary laws' or principles have been proposed for explaining progress and predictability during the history of life, including: (1) Linnaeus's law of increased complexity, formulated in pre-evolutionary times and developed later by Lamarck; (2) Cope's Law of the Unspecialized, which stated that evolutionary novelties associated with new major taxa are more likely to originate from a generalised, rather than a specialised, member of an ancestral taxon ( $\mathrm{Hs}_{2}$ Depéret's law of progressive specialisation of phyletic branches, which led to the arrest in development and extinction of over-specialised forms); (3) Cope's law for the gradual increase of body size (commonly named as Cope's rule, a term coined by Rensch 1948), which is a special case of the Law of the Unspecialized, as most animal clades start at small body size (and given that a lower size limit per body plan does exist, the apparent directionality in diversification towards larger sizes would be an grtefact of increasing variance in body size through time, a manifestation of a 'passive' trend); (4) Dollo's law on irreversibility of evolution; (5) Williston's law on the tendency to reduce the number of repeated similar structures (e.g., vertebrae and teeth in tetrapods, or body appendages in arthropods) to fewer differently §pecialised units; (6) Berg's law of nomogenesis, based on the concept of 'Waagen transmutations' (i.e., mass mutations that simultaneously affect a vast number of individuals and proceed in a determined direction); and (7) Nägeli's law of inertia in the organic world, Hyatt's theory of racial senescence and Schindewolf's typostrophic theory, the three describing an intrinsic tendency within lineages to degenerating into a 'senile' phase prior to becoming extinct (Cope 1887, 1896; Depéret 1909; Simpson 1961; Berg 1969; Gould 1970, 1977, 1980, 1988; Stanley 1973; Saunders and Ho 1976, 1981; Devillers and Chaline 1993; DiMichele 1995; Shanahan 2011; Raia and Fortelius 2013). 
These empirical generalisations were incorrectly called 'evolutionary laws' on the basis of what the early evolutionary palaeontologists knew on the fossil record (Simpson 1961; Gould 1977). Several of them are considered as unfounded, because they imply orthogenesis and 'lineages are not impelled by some internal or supernal force to keep on evolving indefinitely in the same direction' (Simpson 1961, p. 1685). Others have been more or less profoundly modified, as in the case of Dollo's law, 'which reflected a correct generalisation now embraced in the broader-statement of evolutionary irrevocability: organisms do not, as a rule, wholly return to any ancestral condition nor yet wholly lose effects of any ancestral condition' (Simpson 1961, p. 1685). However, even under this reformulation, the scientific nomological character of Dollo's law is highly questionable, as convincingly argued by Gould (1970), because the statement of irreversibility can be easily turned into a non-falsifiable claim. Finally, in a few cases there is evidence in the fossil record of statistical regularity for the patterns that these 'evolutionary laws' account for (Simpson 1961). This is the case of Cope's rule for the evolution of body size in mammals (Stanley 1973; Alroy 1998; Hone and Benton 2005) and Williston's law for the evolution of tagmosis patterns in arthropod appendages (Flessa et al. 1975), which both have been validated as empirical generalisations open to exception (Simpson 1961), as happens in the case of Bergmann's and Allen's ecogeographic rules (Ashton et al. 2000; Queiroz and 1570 Ashton 2004). In fact, these 'rules' are not genuine scientific laws; at best, they are ceteris paribus generalisations lacking of necessity and universality.

\section{Concluding remarks}

There is no doubt that biostratigraphy is a useful tool for refining the chronology of the earliest hominin settlements in Western Europe, in particular when combined with magnetostratigraphy and standard radiometric methods

1580 such as ESR (e.g., Oms et al. 2000; Duval et al. 2012; Toro et al. 2013; Cuenca-Bescós et al. 2015). However, although somewhat tempting, the conversion of biostratigraphic methods into a numerical dating tool based on an orthoevolutionary approach, as the one used by Lozano-

1585 Fernández, Blain, et al. (2014), faces numerous conceptual and methodological problems. The apparent agreement between the pseudo numerical ages obtained with this 'chronometric tool' and the existing chronostratigraphic framework of the Orce sites should not be considered at all as evidence in support of the reliability of such orthoevolutionary approach. Although it is true that there is a genuine long-term trend to increasing tooth size in arvicolids during the Pleistocene, this trend is far from describing a rectilinear, orthogenetic path. For this reason, very general sense (Palmqvist et al. 2014) and any further chronometric interpretation should be considered with caution.

\section{Disclosure statement}

No potential conflict of interest was reported by the authors.

\section{Funding}

This study has been funded by the 'Consejería de Educación, Cultura y Deportes' (contract Exp. B090678SV18BC) and 'Consejería de Economía, Innovación y Ciencia' (project P11HUM-7248) of the Junta de Andalucía. MD is currently the recipient of an International Outgoing Fellowship from the People Programme (Marie Curie Actions) of the European Union's Seventh Framework Programme [FP7/2007-2013] under REA grant agreement [PIOF-GA-2013-626474]. Constructive remarks from two anonymous reviewers are also acknowledged.

\section{References}

Agustí J, Blain H-A, Furió M, De Marfá R, Santos-Cubedo A. 2010. The early Pleistocene small vertebrate succession from the Orce region (Guadix-Baza Basin, SE Spain) and its bearing on the first human occupation of Europe. Quat Int. 223-224:162-169.

Agustí J, Lordkipanidze D. 2011. How African was the early human dispersal out of Africa? Quat Sci Rev. 30:1338-1342.

Agustí J, Lozano-Fernández I, Oms O, Piñero P, Furió M, López-García JM, Martínez-Navarro B. Forthcoming 2015. Early to Middle Pleistocene rodent biostratigraphy of the Guadix-Baza basin (SE Spain). Quat Int. doi:10.1016/j.quaint.2014.11.005.

Alberdi MT, Alonso MA, Azanza B, Morales. 2001. Vertebrate taphonomy in circum-lake environments: three cases in the Guadix-Baza Basin (Granada, Spain). Palaeogeogr Palaeoclimatol Palaeoecol. 165(1-2):1-26. doi:10.1016/S0031-0182(00)00151-6.

Alroy J. 1998. Kope's rule and the dynamics of body mass evolution in North American fossil mammals. Science. 280(5364):731-734. doi: 10.1126/science. 280.5364 .731 .

Antón SC, Swisher III CC. 2004. Early dispersals of Homo from Africa. Ann Rev Anthropol. 33:271-296.

Arnold LJ, Demuro M, Parés JM, Pérez-González A, Arsuaga JL, Bermúdez de Castro JM, Carbonell E. Forthcoming 2015. Evaluating the suitability of extended-range luminescence dating techniques over Early and Middle Pleistocene timescales: published datasets and case studies from Atapuerca, Spain. Quat Int. doi: 10.1016/j.quaint. 2014.08.010.

Arribas A, Garrido G, Viseras C, Soria JM, Pla S, Solano JG, Garcés M, Beamud E, Carrión JS. 2009. A mammalian lost world in southwest Europe during the Late Pliocene. PLoS ONE. 4(9):e7127. doi:10. 1371/journal.pone.0007127.

Arribas A, Palmqvist P. 1999. On the ecological connection between sabretooths and hominids: faunal dispersal events in the lower Pleistocene and a review of the evidence for the first human arrival in Europe. J Archaeol Sci. 26(5):571-585. doi:10.1006/jasc.1998.0346.

Arribas A, Palmqvist P. 2002. The first human dispersal to Europe: remarks on the archaeological and palaeoanthropological record from Orce (Guadix-Baza basin, south-eastern Spain). Hum Evol. 17(1-2):55-邓7. doi:10.1007/BF02436429.

Ashton KG, Tracy MC, Queiroz A. 2000. Is Bergmann's rule valid for mammals? Am Nat. 156(4):390-415. doi:10.1086/303400.

Bar-Yosef O, Belfer-Cohen A. 2001. From Africa to Eurasia - early dispersals. Quat Int. 75(1):19-28. doi:10.1016/S1040-6182(00) 00074-4.

Berg LS. 1969. Nomogenesis or evolution determined by law. Cambridge (MA): MIT Press.

Berger GW, Pérez-González A, Carbonell E, Arsuaga JL, Bermúdez de Castro JM, Ku TL. 2008. Luminescence chronology of cave 
sediments at the Atapuerca paleoanthropological site, Spain. J Hum Evol. 55(2):300-311. doi:10.1016/j.jhevol.2008.02.012.

Bermúdez de Castro JM, Arsuaga JL, Carbonell E, Rosas A, Martínez I, Mosquera M. 1997. A hominid from the lower Pleistocene of Atapuerca, Spain: possible ancestor to Neandertals and modern humans. Science. 276:1392-1395.

Bermúdez de Castro JM, Martinón-Torres M. 2013. A new model for the evolution of the human Pleistocene populations of Europe. Quat Int. 295:102-112.

Bermúdez de Castro JM, Martinón-Torres M, Gómez Robles A, Leyre Prado MA, Carbonell E. 2010. New human evidence of the Early Pleistocene settlement of Europe, from Sima del Elefante site (Sierra de Atapuerca, Burgos, Spain). Quat Int. 223-224:431-433.

Blomberg SP, Garland T. 2002. Tempo and mode in evolution: phylogenetic inertia, adaptation and comparative methods. J Evol Biol. 15(6):899-910. doi:10.1046/j.1420-9101.2002.00472.x.

Bowler PJ. 1979. Theodor Eimer and orthogenesis: evolution by definitely directed variation. J Hist Med Allied Sci. XXXIV(1): 40-73. doi:10.1093/jhmas/XXXIV.1.40.

1665 Bowler PJ. 1989. Evolution: the history of an Idea. University of California Press.

Bowler PJ. 1992. The eclipse of Darwinism. Johns Hopkins University Press.

Braga JC, Rivas P. 1986. Si hoy es martes, esto es Bélgica: problemas bioestratigráficos y recurrencias morfológicas en los ammonoideos del Jurásico inferior. In: Villas E, editor. Memorias I Jornadas de Paleontología. Diputación General de Aragón; p. 61-70.

Campaña I, Pérez-González A, Benito-Calvo A, Bermúdez de Castro JM, Carbonell C. 2014. Sedimentary analyses and revised sedimentary facies of Gran Dolina site (Sierra de Atapuerca, Burgos). Proceedings of the XVII World UISPP Congress. 2014:58.

Carbonell E, Bermúdez de Castro JM, Parés JM, Pérez-González A Cuenca-Bescós G, Ollé A, Mosquera M, Huguet R, van der Made J, Rosas A, et al. 2008. The first hominin of Europe. Nature. 452(7186): 465-469. doi:10.1038/nature06815.

Carbonell E, Mosquera M, Rodríguez XP, Sala R, van der Made J. 1999. Out of Africa: the dispersal of the earliest technical systems reconsidered. J Anthropol Archaeol. 18(2):119-136. doi:10.1006/ jaar.1998.0331.

1680 Carbonell E, R_odríguez XP. 1994. Early Middle Pleistocene deposits and artefacts in the Gran Dolina site (TD4) of the 'Sierra de Atapuerca' (Burgos, Spain). J Hum Evol. 26(4):291-311. doi:10.1006/jhev. 1994.1018.

Carbonell E, Sala R, Rodríguez XP, Mosquera M, Ollé A, Vergès JM, Martínez-Navarro B, Bermúdez de Castro JM. 2010. Early hominid dispersals: a technological hypothesis for 'out of Africa'. Quat Int. $223-224: 36-44$.

Cope ED. 1885. On the evolution of the Vertebrata, progressive and retrogressive (continued). Am Nat. 19(4):341-353. doi:10.1086/ 273923.

Cope ED. 1887. The origin of the fittest. New York (NY): Appleton.

Cope ED. 1896. Primary factors of organic evolution. Chicago (IL): Open Court.

Cuenca-Bescós G, Agustí J, Lira J, Rubio MM, Rofes J. 2010. A new species of water vole from the Early Pleistocene of Southern Europe. Acta Palaeont Pol. 55:565-580.

Cuenca-Bescós G, Blain H-A, Rofes J, Lozano-Fernández I, LópezGarcía JM, Duval M, Galán J, Núñez-Lahuerta C. 2015. Comparing two different Early Pleistocene microfaunal sequences from the caves of Atapuerca, Sima del Elefante and Gran Dolina (Spain): biochronological implications and significance of the Jaramillo subchron. Quat Int.. doi:10.1016/j.quaint.2014.12.059.

Cuenca-Bescós G, Melero-Rubio M, Rofes J, Martínez I, Arsuaga JL, Blain HA, López-García JM, Carbonell E, Bermudez de Castro JM. 2011. The Early Middle Pleistocene environmental and climatic change and the human expansion in Western Europe: a case study with small vertebrates (Gran Dolina, Atapuerca, Spain). J Hum Evol. 60:481-491.

de Lumley H, Lordkipanidze D, Féraud G, García T, Perrenoud Ch, Falguères Ch, Gagnepain J, Saos Th, Voinchet P. 2002. Spatation par la méthode ${ }^{40} \mathrm{Ar} /{ }^{39} \mathrm{Ar}$ de la couche de cendres volcaniques (couche vi) de dmanissi (géorgie) qui a livré des restes d’hominidés fossiles de 1.81 Ma. Comp Rend Palevol. 1(3):181 - 189. doi:10.1016/S16310683(02)00023-4.

Dennell RW. 2003. Dispersal and colonisation, long and short chronologies: how continuous is the early pleistocene record for hominids outside East Africa. J Hum Evol. 45(6):421-440. doi:10. 1016/j.jhevol.2003.09.006

Dennell R, Roebroeks W. 1996. The earliest colonization of Europe: the short chronology revisited. Antiquity. 70:535-542.

Dennell R, Roebroeks W. 2005. An Asian perspective on early human dispersal from Africa. Nature. 438(7071):1099-1104. doi:10.1038/ nature 04259 .

Depéret C. 1909. The transformations of the animal world. International Scientific Series, vol. XCIV London: Kegan Paul, Trench, Trübner.

Devillers C, Chaline C. 1993. Evolution: an evolving theory. Berlin and Heidelberg: Springer.

DiMichele WA. 1995. Basic questions in paleontology: geologic time, organic evolution, and biological systematics. Rev Palaeobot Palynol. 84(3-4):481-482. doi:10.1016/0034-6667(95)90007-1.

Duval M, Bahain JJ, Falguères C, Garcia J, Guilarte V, Grün R, Martínez K, Moreno D, Shao Q, Voinchet P. Forthcoming 2015. Revisiting the ESR chronology of the Early Pleistocene hominin occupation at Vallparadís (Barcelona, Spain). Quat Int.. doi:10.1016/j.quaint.2014. 08.054 .

Duval M, Falguères C, Bahain JJ. 2012. Age of the oldest hominin settlements in Spain: contribution of the combined U-series/ESR dating method applied to fossil teeth. Quat Geochronol. 10:412-417. doi:10.1016/j.quageo.2012.02.025

Duval M, Falguères C, Bahain JJ, Krün R, Shao Q, Aubert M, Dolo JM, Agustí J, Martínez-Navarro B, Palmqvist P, Toro-Moyano I. 2012. On the limits of using combined U-series/ESR method to date fossil teeth from two Early Pleistocene archaeological sites of the Orce area (Guadix-Baza basin, Spain). Quat Res. 77(3):482-191. doi:10. 1016/j.yqres.2012.01.003.

Duval M, Moreno D, Shao Q, Voinchet P, Falguères C, Bahain J-J, Sarcía T, Garcia J, Martínez K. 2011. Ratación por ESR del yacimiento arqueológico del Pleistoceno inferior de Vallparadís (Terrassa, Cataluña, España). Trabajos Prehist. 68(1):7-24. doi:10.3989/tp. 2011.11056.

Eimer GHT. 1898. On orthogenesis and the importance of natural selection in species formation. Chicago (IL): Open Court.

Espigares MP, Martínez-Navarro B, Palmqvist P, Ros-Montoya S, Toro I, Agustí J, Sala R. 2013. _Homo vs. Pachycrocuta: earliest evidence of competition for an elephant carcass between scavengers at Fuente Nueva-3 (Orce, spain). Quat Int. 295:113-125. doi:10.1016/j.quaint. 2012.09.032.

Falguères Ch, Bahain JJ, Yokoyama Y, Arsuaga JL, Bermúdez de Castro JM, Carbonell E, Bischoff JL, Dolo JM. 1999. Earliest humans in Europe: the age of TD6 Gran Dolina, Atapuerca, Spain. J Hum Evol. $37: 343-352$.

Flessa KW, Powers KV, Cisne JL. 1975. Specialization and evolutionary longevity in the Arthropoda. Paleobiology. 1:71-81.

Sabounia L, de Lumley MA, Vekua A, Lordkipanidze D, de Lumley H. 2002. Récouverte d'un nouvel hominidé à Dmanissi (Transcaucasie, Géorgie). Comp Rend Palevol. 1(4):243-253. doi:10.1016/S16310683(02)00032-5.

Gabunia L, Vekua A. 1995. A Plio-Pleistocene hominid from Dmanisi, East Georgia, Caucasus. Nature. 373(6514):509-512. doi:10.1038/ $373509 \mathrm{a} 0$.

Gabunia L, Vekua A, Lordkipanidze D, Swisher III CC, Ferring R, Justus A, Nioradze M, Tvalchrelidze M, Anton SC, Bosinski G, et al. 2000. Earliest Pleistocene hominid cranial remains from Dmanisi, Republic of Georgia: taxonomy, geological setting, and age. Science. 288(5468):1019-1025. doi:10.1126/science.288.5468. 1019.

García J, Martínez K, Carbonell E. 2013a. The Early Pleistocene stone tools from Vallparadís (Barcelona, Spain): rethinking the European Mode 1. Quat Int. 316:94-114.

García J, Martínez K, Cuenca-Bescós G, Carbonell E. 2014. Human occupation of Iberia prior to the Jaramillo magnetochron (>1.07 Myr). Quat Sci Rev. 98:84-99.

García J, Landeck G, Martínez K, Carbonell E. 2013. Hominin dispersals from the Jaramillo subchron in central and south-western Europe: 
Untermassfeld (Germany) and Vallparadís (Spain). Quat Int. 316: $73-93$.

Gómez Cano AR, Hernández Fernández M, Álvarez-Sierra MA. 2011. Biogeographic provincialism in rodent faunas from the Iberoccitanian Region (southwestern Europe) generates severe diachrony within the Mammalian Neogene (MN) biochronologic scale during the Late Miocene. Palaeogeogr Palaeoclimatol Palaeoecol. 307: 193-204.

Gould SJ. 1970. Dollo on Dollo's law: irreversibility and the status of evolutionary laws. J Hist Biol. 3(2):189-212. doi:10.1007/ BF00137351.

Gould SJ. 1974. The origin and function of 'bizarre' structures: antler size and skull size in the 'Irish Elk,' Megaloceros giganteus. Evolution. 28(2):191-220. doi:10.2307/2407322.

Gould SJ. 1977. Eternal metaphors of palaeontology. In: Hallan A, editor. Patterns of evolution, as Illustrated by the Fossil Record, 1-26. Amsterdam: Elsevier Scientific.

Gould SJ. 1980. The promise of paleobiology as a nomothetic, evolutionary discipline. Paleobiology. 6:96-118.

Gould SJ. 1988. Trends as changes in variance: a new slant on body size evolution. J Paleontol. 62:319-329.

Gould SJ. 2002. The structure of evolutionary theory. Cambridge (MA): Belknap Press of Harvard University Press.

Gould GC, MacFadden BJ. 2004. Chapter 17: gigantism, dwarfism, and Cope's rule: 'nothing in evolution makes sense without a phylogeny'. Bull Am Mus Nat Hist. 285:219-237.

Gúerin C, Faure M. 1997. The wild boar (Sus scrofa priscus) from the post- Villafranchian lower Pleistocene of Untermassfeld. In: Kahlke R-D, editor. Das Pleistozän von Untermassfeld bei Meningen (Thüringen). Bonn: Romisch-Germanisches Zentralmuseum; p. $375-383$.

Guyer MF. 1922. Orthogenesis and serological phenomena. Am Nat. 56(643):116-133. doi:10.1086/279852.

Hart J. 1830. A description of the skeleton of the fossil deer of Ireland, Cervus Megaceros; drawn up at the insistence of the Committee of Natural Philosophy of the Royal Dublin Society. Dublin: R. Graisberry.

Heinrich W-D. 1978. Zur biometrischen Erfassung eines Evolutionstrends bei Arvicola (Rodentia, Mammalia) aus dem Pleistozän Thüringens. Säugetierkd. Inf. 2:3-21.

Hone DW, Benton MJ. 2005. The evolution of large size: how does Cope's Rule work? TREE. 20:4-6.

Huxley JS. 1931. 46 . The relative size of antlers in deer. Proc Zool Soc Lond. 101(3):819-864. doi:10.1111/j.1096-3642.1931.tb01047.x.

Huxley JS. 1932. Problems of relative growth. London: MacVeagh.

Jepsen GL. 1949. Selection, orthogenesis, and the fossil record. Proc Am Phil Soc. 93:479-500.

Jiménez-Arenas JM, Palmqvist P, Pérez-Claros JA. 2011a. A probabilistic approach to the craniometric variability of the genus Homo and inferences on the taxonomic affinities of the first human population dispersing out of Africa. Quat Int. 243:219-230.

Jiménez-Arenas JM, Santonja M, Botella M, Palmqvist P. 2011b. The oldest handaxes in Europe: fact or artefact? J Archaeol Sci. 38: $3340-3349$.

Johnston H. 1903. British mammals. London: Hutchinson.

Lang WD. 1923. Evolution: a resultant. Proc Geol Assoc. 34(1):7-20. doi:10.1016/S0016-7878(23)80017-7.

Levit GS, Olsson L. 2006. Evolution on rails: mechanisms and levels of orthogenesis. Ann Hist Philos Biol. 11:99-138.

1805 Lister AM. 1992. Mammalian fossils and quaternary biostratigraphy. Quat Sci Rev. 11(3):329-344. doi:10.1016/0277-3791(92)90004-R.

Lister AM. 1994. The evolution of the giant deer, Megaloceros giganteus (Blumenbach). Zool J Linn Soc. 112(1-2):65-100. doi:10.1111/j. 1096-3642.1994.tb00312.x.

Lister AM. 2013. Speciation and evolutionary trends in Quaternary vertebrates. Encycl Quat Sci. :723-732.

1810 Lister AM, Sher AV. 2001. The origin and evolution of the woolly mammoth. Science. 294(5544):1094-1097. doi:10.1126/science. 1056370.

Lister AM, Sher AV, van Essen H, Wei G. 2005. The pattern and process of mammoth evolution in Eurasia. Quat Int. 126-128:49-64. doi:10. 1016/j.quaint.2004.04.014.
Lordkipanidze D, Jashashvili T, Vekua A, de León MSP, Zollikofer CPE, Rightmire GP, Pontzer H, Ferring R, Oms O, Tappen M, et al. 2007. Rostcranial evidence from early Homo from Dmanisi, Georgia. Nature. 449(7160):305-310. doi:10.1038/nature06134.

Lordkipanidze D, Ponce de León MS, Margvelashvili A, Rak Y, Rightmire GP, Vekua A, Zollikofer CP. 2013. A complete skull from Dmanisi, Georgia, and the evolutionary biology of early Homo. Science. 342(6156):326-331. doi:10.1126/science.1238484.

Lordkipanidze D, Vekua A, Ferring R, Rightmire GP, Agusti J, Kiladze G, Mouskhelishvili A, Nioradze M, de León MSP, Tappen M, et al. 2005. Anthropology: the earliest toothless hominin skull. Nature. 434(7034):717-718. doi:10.1038/434717b.

Lozano-Fernández I. 2014. Evolución de Mimomys savini en la Península Ibérica durante el Pleistoceno inferior; implicaciones biocronológicas y paleoambientales en el estudio de las primeras poblaciones humanas en Europa [Unpublished $\mathrm{PhD}$ Thesis dissertation] Universitat Roviri Virgili, Tarragona, $287 \mathrm{pp}$.

Lozano-Fernández I, Agustí J, Cuenca-Bescós G, Blain H-A, LópezGarcía JM, Vallverdú J. 2013. Pleistocene evolutionary trends in dental morphology of Mimomys savini (Rodentia, Mammalia) from Iberian Peninsula and discussion about the origin of the genus Arvicola. Quaternaire. 24:179-190.

Lozano-Fernández I, Bañuls-Cardona S, Blain HA, López-García J, Vallverdu J, Agusti J, Cuenca-Bescós G. 2014. Biochronological data inferred from the Early Pleistocene small mammals of the Barranc de la Boella site (Tarragona, north-eastern Spain). J Quat Sci. 29:722-728.

Lozano-Fernández I, Blain HA, López-García JM, Agustí J. 2014. Biochronology of the first hominid remains in Europe using the vole Mimomys savini: Fuente Nueva 3 and Barranco León D, GuadixBaza Basin, south-eastern Spain. Hist Biol: Int J Paleobiol.. doi:10. 1080/08912963.2014.920015.

Lozano-Fernández I, Cuenca-Bescós G, Blain HA, López-García JM, Agustí J. 2013. Mimomys savini size evolution in the Early Pleistocene of south-western Europe and possible biochronological implications. Quat Sci Rev. 76:96-101.

MacFadden BJ. 1994. Fossil horses: systematics, paleobiology, and evolution of the Family Equidae. Cambridge University Press.

Madurell-Malapeira J, Alba DM, Minwer-Barakat R, Aurell-Garrido J, Moyà-Solà S. 2012. Early human dispersals into the iberian peninsula: a comment on and. J Hum Evol. 62(1):169-173. doi:10. 1016/j.jhevol.2011.10.005

Madurell-Malapeira J, Minwer-Barakat R, Alba DM, Garcés M, Gómez $\mathrm{M}$, Aurell-Garrido J, Ros-Montoya S, Moyà-Solà S, Berástegui X. 2010. The Vallparadís section (Terrassa, Iberian Peninsula) and the latest Villafranchian faunas of Europe. Quat Sci Rev. 29(27-28): 3972-3982. doi:10.1016/j.quascirev.2010.09.020.

Maglio VJ. 1973. Origin and evolution of the Elephantidae. Trans Am Philos Soc. 63(3):1-149. doi:10.2307/1006229.

Marsh OC. 1874. Notice of new Equine mammals from the Tertiary Formation. Ann Mag N Hist: Ser 4. 13:397-400.

Martin RA. 2014. A critique of vole clocks. Quat Sci Rev. 94:1-6. doi:10. 1016/j.quascirev.2014.03.004

Martín-Penela AJ. 1988. Los Grandes mamíferos del yacimiento achelense de la Solana del Zamborino, Fonelas (Granada, España). Antropol Paleoecol Humana. 5:29-235.

Martínez K, García J, Burjachs F, Yll R, Carbonell E. 2014. Early human occupation of Iberia: the chronological and palaeoclimatic inferences from Vallparadís (Barcelona, Spain). Quat Sci Rev. 85:136-146.

Martínez K, Garcia J, Carbonell E. 2013. Hominin multiple occupations in the Early and Middle Pleistocene sequence of Vallparadís (Barcelona, Spain). Quat Int. 316:115-122.

Martínez K, Garcia J, Carbonell E, Agustí J, Bahain J-J, Blain H-A, Burjachs F, Cáceres I, Duval M, Falguères C, Gómez M, Huguet R. 2010. A new lower Pleistocene archeological site in Europe (Vallparadís, Barcelona, Spain). Proc Natl Acad Sci USA. 107: $5762-5767$.

Martínez-Navarro B. 2004. Hippos, pigs, bovids, sabertoothed tigers, monkeys and hominids dispersals during late Pliocene and Early Pleistocene times through the Levantine Corridor. In: Goren-Inbar N, Speth JD, editors. Human paleoecology in the Levantine Corridor. Jerusalem: Oxbow Books; p. 37-51.
1820 
Martínez-Navarro B. 2010. Early Pleistocene faunas of Eurasia and hominin dispersals. In: Fleagle JG, et al., editors. Out of Africa I: the first Hominin colonization of Eurasia. New York (NY): Springer; p. 207-224.

Martínez-Navarro B, Palmqvist P. 1995. Presence of the African machairodont Megantereon whitei (BROOM, 1937) (Felidae, Carnivora, Mammalia) in the lower Pleistocene site of Venta Micena (Orce, Granada, Spain), with some considerations on the origin, evolution and dispersal of the genus. J Archaeol Sci. 22:569-582.

Martínez-Navarro B, Turq A, Agustí J, Oms O. 1997. Fuente Nueva-3 (Orce, Granada, Spain) and the first human occupation of Europe. J Hum Evol. 33:611-620.

Masini F, Della-Valle RG, Abbazzi L, Maul L. 1999a. L'ottimizzazione dei caratteri evolutivi viene raggiunta con un decadimento esponenziale? L'evoluzione del genere Microtus. In: Evoluzione degli Animali, Evoluzione delle Piante, Evoluzione dei Microrganismi: Strategie a Confronto. $7^{\circ}$ Incontro ltaliano di Biologia Evoluzionistica. p. 29-31.

Masini F, Della-Valle RG, Abbazi L, Maul LC. 1999b. Un modelo per la dinamiche evolutive in paleobiologia. In: Capire LA VITA. Modelli matematici e teorie qualitative. Syst Nat. 2 . p. 135-169.

Maul LC, Masini F, Abbazi L, Turner A. 1998a. The use of different morphometric data for absolute age calibration of some South- and Middle European arvicolid populations. Palaeontogr Ital. 85: $111-151$.

Maul L, Masini F, Abbazzi L, Turner A. 1998b. Geochronological application of evolutionary trends in the dentition of fossil Arvicolidae. Mededelingen Nederlands Instituut voor Geowetenschappen TNO. 60:565-572.

Maul L, Masini F, Parfitt SA, Rekovets L, Savorelli A. 2014 Evolutionary trends in arvicolids and the endemic murid mikrotia - new data and a critical overview. Quat Sci Rev. 96:240-258. doi: 10.1016/j.quascirev.2013.09.017.

Mayr E. 1976. Evolution and the diversity of life: selected essays. Harvard University Press.

McShea DW. 1998. Possible largest-scale trends in organismal evolution: eight 'live hypotheses'. Ann Rev Ecol Syst. 29(1):293-318. doi:10. 1146/annurev.ecolsys.29.1.293

Metcalf MM. 1928. Trends in evolution: a discussion of data bearing upon orthogenesis?. J Morphol Physiol. 45(1):1-45. doi:10.1002/ jmor.1050450102.

Moncel M-H. 2010. Oldest human expansions in Eurasia: favouring and limiting factors. Quat Int. 223-224:1-9.

Montagu MFA. 1955. Time, morphology, and neoteny in the evolution of man. Am Anthrop New Ser. 57(1):13-27. doi:10.1525/aa.1955.57.1. 02a00030.

Moreno-García D. 2011. Datation par ESR de quartz optiquement blanchis (ESR-OB) de la région de Atapuerca (Burgos, Espagne). Application au site préhistorique de Gran Dolina (contexte karstique) et aux systèmes fluviatiles quaternaires de l'Arlanzón et l'Arlanza [Ph.D. thesis]. [Tarragona]: Universitat Rovira i Virgili.

Moullé PE, Lacombat F, Echassoux A. 2006. Apport des grands mammifères de la grotte du Vallonnet (Roquebrune-Cap-Martin, Alpes-Maritimes, France) à la connaissance du biochronologique de la seconde moité du Pléistocene inférieur d'Europe. L'Anthropologie. 110:837-849.

Muttoni G, Scardia G, Kent DV, et al. 2013. A critique of evidence for human occupation of Europe older than the Jaramillo subchron $(\sim 1 \mathrm{Ma})$ : comment on 'the oldest human fossil in Europe from orce (Spain)' by. J Hum Evol. 65(6):746-749. doi:10.1016/j.jhevol.2013. 08.005 .

Newell ND. 1949. Phyletic size increase, an important trend illustrated by fossil invertebrates. Evolution. 3(2):103-124. doi:10.2307/2405545.

Nikitas P, Nikita E. 2005. A study of hominin dispersal out of Africa using computer simulations. J Hum Evol. 49(5):602-617. doi:10. 1016/j.jhevol.2005.07.001.

1920 Norusis M. 2011. IBM SPSS statistics 19 guide to data analysis. Prentice Hall Press.

Oms O, Parés JM, Martínez-Navarro B, Agustí J, Toro I, MartínezFernández G, Turq A. 2000. Early human occupation of Western Europe: paleomagnetic dates for two paleolithic sites in Spain. Proc Natl Acad Sci USA. 97(19):10666-10670. doi:10.1073/pnas. 180319797.
Palmqvist P, González-Donoso JM, De Renzi M. 2014. Rectilinear evolution in arvicoline rodents and numerical dating of Iberian Early Pleistocene sites. Quat Sci Rev. 98:100-109. doi:10.1016/j. quascirev.2014.06.002.

Palmqvist P, Martínez-Navarro B, Toro I, Espigares MP, Ros-Montoya S, Torregrosa V, Pérez-Claros JA. 2005. Ŗéévaluation de la présence humaine au Pléistocène inférieur dans le sud de L'espagne. L'Anthropol. 109(3):411-450. doi:10.1016/j.anthro.2005.06.001.

Palmqvist P, Torregrosa V, Pérez-Claros JA, Martínez-Navarro B, Turner A. 2007. A re-evaluation of the diversity of Megantereon (Mammalia, Carnivora, Machairodontinae) and the problem of species identification in extinct carnivores. J Vert Paleontol. 27(1):160-175. doi:10. 1671/0272-4634(2007)27[160:AROTDO]2.0.CO;2.

Paupe P, Guérin C, Labe B, Rousselières F. 2010. Les mammouths (Proboscidea, Elephantidae) du Pléistocène moyen final de l'aven de Romain-la-Roche (Doubs, France). Rev Paléobiol. 29:803-825.

Pevzner MA, Vangengeim EA. 2001. Age of some European localities with elephant remains determined by the biometric method. In: The World of Elephants. Proceedings of the First International Congress, Roma. p. 129-132.

Plate L. 1903. Uber die Bedeutung des Darwinischen Selectionsprinzip und Probleme der Artbildung. Leipzig: Engelmann.

Queiroz AD, Ashton KG. 2004. The phylogeny of a species-level tendency: Species heritability and possible deep origins of Bergmann's rule in tetrapods. Evolution. 58(8):1674-1684. doi:10. 1111/j.0014-3820.2004.tb00453.x.

Raia P, Fortelius M. 2013. Cope's Law of the Unspecialized, Cope's Rule, and weak directionality in evolution. Evol Ecol Res. 15:1-10.

Rensch B. 1948. Histological changes correlated with evolutionary changes of body size. Evolution. 2(3):218-230. doi:10.2307/ 2405381 .

Roberts MB, Stringer CB, Parfitt SA. 1994. A hominid tibia from Middle Pleistocene sediments at Boxgrove, UK. Nature. 369(6478): 311-313. doi:10.1038/369311a0.

Roebroeks W, van Kolfschoten T. 1994. The earliest occupation of Europe: a short chronology. Antiquity. 68:489-503.

Rook L, Martínez-Navarro B. 2010. Villafranchian: the long story of a Plio-Pleistocene European large mammal biochronologic unit. Quat Int. 219(1-2):134-144. doi:10.1016/j.quaint.2010.01.007.

Ros-Montoya S. 2010. Los Proboscídeos del Plio-Pleistoceno de las Cuencas de Guadix-Baza y Granada. [Ph.D. dissertation]. Universidad de Granada, 404 p.

Ros-Montoya S, Madurell-Malapeira J, Martínez-Navarro B, Espigares MP, Palmqvist P. 2012. Late Villafranchian Mammuthus meridionalis (Nesti, 1825) from the Iberian peninsula: dentognathic remains from Incarcal-I (Crespià, Girona) and Venta Micena (Orce, Granada). Quat Int. R76-277:17-22. doi:10.1016/j.quaint.2012.03. 007.

Saunders PT, Ho MW. 1976. On the increase in complexity in evolution. J Theor Biol. 63(2):375-384. doi:10.1016/0022-5193(76)90040-0.

Saunders PT, Ho MW. 1981. On the increase in complexity in evolution II. The relativity of complexity and the principle of minimum increase. J Theor Biol. 90(4):515-530. doi:10.1016/0022-5193(81) 90303-9.

Schindewolf OH. 1936. Paläontologie, Entwicklungslehre und Genetik: Kritik und Synthese. Berlin: Bornträger.

Schindewolf OH. 1945. Darwinismus oder Typostrophismus? Arb. Ungarischen Biol. Forsch.-Inst. 16:104-177.

Schindewolf OH. 1950. Grundfragen der Paläontologie: Geologische Zeitmessung, organische Stammesentwicklung, biologische Systematik. E. Germany: Schweizerbart, Stuttgart.

Schopf TJ. 1977. Patterns and themes of evolution among the Bryozoa. In: Hallan A, editor. Patterns of evolution, as Illustrated by the Fossil Record. Amsterdam: Elsevier Scientific; p. 159-207.

Scott GR, Gibert Ll, Gibert J. 2007. Magnetostratigraphy of the Orce region (Baza Basin), SE Spain: New chronologies for Early Pleistocene faunas and hominid occupation sites. Quat Sci Rev. 26(3-4):415-435. doi:10.1016/j.quascirev.2006.09.007.

Shanahan T. 2011. Phylogenetic inertia and Darwin's higher Law. Stud Hist Phil Biol Biomed Sci. 42(1):60-68. doi:10.1016/j.shpsc.2010. 11.013 .

Simpson GG. 1944. Tempo and mode in evolution. New York (NY): Columbia University Press. 
Simpson GG. 1950. Some principles of historical biology bearing on human origins. Cold Spring Harbor Symp Quant Biol. 15:55-66. doi:10.1101/SQB.1950.015.01.008.

Simpson GG. 1953. The major features of evolution. New York (NY): Columbia University Press.

Simpson GG. 1961. Some problems of vertebrate paleontology: the study of fossil vertebrates elucidates the general principles of evolutionary biology. Science. 133(3465):1679-1689. doi:10.1126/science.133. 3465.1679 .

Stanley SM. 1973. An explanation for Cope's rule. Evolution. 27(1): 1-26. doi: $10.2307 / 2407115$.

Moyano I, Barsky D, Cauche D, Celiberti V, Grégoire S, Lebegue F, Moncel MH, de Lumley H. 2011. The archaic stone tool industry from Barranco León and Fuente Nueva 3, (Orce, Spain): evidence of the earliest hominin presence in southern Europe. Quat Int. 243(1): 80-91. doi:10.1016/j.quaint.2010.12.011.

Toro-Moyano I, Martínez-Navarro B, Agustí J, Souday C, Bermúdez de Castro JM, Martinón-Torres M, Fajardo B, Duval M, Falguères C, Oms O, et al. 2013. The oldest human fossil in Europe, from Orce (spain). J Hum Evol. 65(1):1-9. doi:10.1016/j.jhevol.2013.01.012.

Turner A, O'Regan HJ. 2007. Afro-Eurasian mammalian fauna and early hominin dispersals. In: Petraglia MD, Allchin B, editors. The evolution and history of human populations in South Asia. p. $23-39$.

Ulett MA. 2014. Making the case for orthogenesis: the popularization of definitely directed evolution (1890-1926). Stud Hist Philos Biol Biomed Sci. 45:124-132. doi:10.1016/j.shpsc.2013.11.009.
Vallverdú J, Saladié P, Rosas A, Huguet R, Cáceres I, Mosquera M, García-Tabernero A, Estalrrich A, Lozano-Fernández I, PinedaAlcalá A, et al. 2014. Age and date for early arrival of the Acheulian in Europe (Barranc de la Boella, la Canonja, Spain). PLoS ONE. 9: e103634. doi:10.1371/journal.pone.0103634

Vangengeim EA, Pevzner MA. 2000. Biometric dating of elephants of the Archidiskodon-Mammuthus lineage. Stratigr Geol Correl. 8:77-83.

Vekua A, Lordkipanidze D, Rightmire GP, Agustí J, Ferring R, Maisuradze G, Mouskhelishvili A, Nioradze M, Ponce de Leon M, Tappen M, et al. 2002. A new skull of early homo from Dmanisi, Georgia. Science. 297(5578):85-89. doi:10.1126/science.1072953.

Von Koenigswald W, Van Kolfschoten T. 1996. The Mimomys-Arvicola boundary and the enamel thickness quotient (SDQ) of Arvicola as stratigraphic markers in the Middle Pleistocene. In: Turner C, editor. The early Middle Pleistocene in Europe. Proceedings of the SEQS Cromer Symposium; Norwich/United Kingdom. Rotterdam: A.A. Balkema; p. 211-226.

Wagner G, Krbetschek M, Degering D, Bahain JJ, Shao Q, Falguères C, Voinchet P, Dolo JM, García T, Rightmire GP. 2010. Radiometric dating of the type-site for Homo heidelbergensis at Mauer, Germany. Proc Natl Acad Sci USA. 107(46):19726-19730. doi:10.1073/pnas. 1012722107

Walton D. 1999. Rethinking the fallacy of hasty generalization. Argumentation. 13(2):161-182. doi:10.1023/A:1026497207240.

Westoll TS. 1950. Some aspects of growth studies in fossils. Proc R Soc Lond Ser B Biol Sci. 137(889):490-509. doi:10.1098/rspb.1950. 0060 